\title{
The F-box protein Cdc4/Fbxw7 is a novel regulator of neural crest development in Xenopus laevis
}

\author{
Alexandra D Almeida ${ }^{1 \dagger}$, Helen M Wise ${ }^{2 \dagger}$, Christopher J Hindley ${ }^{1}$, Michael K Slevin ${ }^{3}$, Rebecca S Hartley ${ }^{4}$, \\ Anna Philpott ${ }^{1 *}$
}

\begin{abstract}
Background: The neural crest is a unique population of cells that arise in the vertebrate ectoderm at the neural plate border after which they migrate extensively throughout the embryo, giving rise to a wide range of derivatives. A number of proteins involved in neural crest development have dynamic expression patterns, and it is becoming clear that ubiquitin-mediated protein degradation is partly responsible for this.

Results: Here we demonstrate a novel role for the F-box protein Cdc4/Fbxw7 in neural crest development. Two isoforms of Xenopus laevis Cdc4 were identified, and designated $x C d c 4 \alpha$ and $x C d c 4 \beta$. These are highly conserved with vertebrate $\mathrm{Cdc} 4$ orthologs, and the Xenopus proteins are functionally equivalent in terms of their ability to degrade Cyclin E, an established vertebrate Cdc4 target. Blocking xCdc4 function specifically inhibited neural crest development at an early stage, prior to expression of c-Myc, Snail2 and Snail.

Conclusions: We demonstrate that $\mathrm{Cdc4}$, an ubiquitin E3 ligase subunit previously identified as targeting primarily cell cycle regulators for proteolysis, has additional roles in control of formation of the neural crest. Hence, we identify Cdc4 as a protein with separable but complementary functions in control of cell proliferation and differentiation.
\end{abstract}

\section{Background}

During the development of multi-cellular organisms, cells receive signals and must elicit the appropriate response. This involves changes in the level and activity of proteins, and targeted proteolysis represents a rapid and irreversible mechanism to block protein function. During regulated proteolysis, proteins are targeted for degradation by covalent attachment of the 76 amino acid protein ubiquitin, and the polyubiquitin chains assembled on the target protein serve as signals for degradation by the $26 \mathrm{~S}$ proteasome. Transfer of ubiquitin onto target proteins is catalyzed by a hierarchical multi-enzyme cascade. An E1 (ubiquitin activating) enzyme forms a thioester linkage with the carboxyl terminus of ubiquitin, in an ATP-dependent process. Ubiquitin is then transferred to an E2 (ubiquitin

\footnotetext{
* Correspondence: ap113@cam.ac.uk

† Contributed equally

${ }^{1}$ Department of Oncology, University of Cambridge, Hutchison-MRC

Research Centre, Addenbrookes Hospital, Hills Road, Cambridge, CB2 OXZ, UK
}

conjugating) enzyme. E3 (ubiquitin ligase) enzymes recruit distinct substrates, allowing ubiquitin transfer, and confer specificity on the ubiquitin proteasome system.

RING (Really Interesting New Gene) E3s are the largest class of E3 ligases, and the human genome encodes approximately 400 proteins with a RING domain [1]. Conserved cysteines and histidines coordinate two zinc ions in the RING domain, which is important for the recruitment and activation of E2 enzymes. Skp1-Cullin1-F-box (SCF) E3 ligases are a large class of modular RING E3 ligases that have the RING component Roc1 (also known as Rbx1 and Hrt1). Cullin1 forms a scaffold to recruit the E2 (via Roc1) and the F-box protein (via binding of the F-box to Skp1) [2,3]. The F-box component of these E3 ligases is variable, and different F-box proteins recruit different substrates via carboxy-terminal domains, allowing SCF ligases to target a huge number of substrates [4]. 
Cdc4 (also known as Fbw7), one of the most extensively studied F-box proteins, was originally identified in Saccharomyces cerevisiae, where it was shown to degrade the cyclin-dependent kinase inhibitor Sic1 [3-8]. In mammals, there are three isoforms of Cdc4: alpha $(\alpha)$, beta $(\beta)$ and gamma $(\gamma)$. These are produced by alternative splicing of three unique $5^{\prime}$ exons to ten common 3' exons, such that the resulting proteins differ only at their amino termini $[9,10]$. In mammals, known Cdc4 substrates include c-Myc, c-Jun, Cyclin E, Notch intracellular domain, c-Myb, sterol regulatory element binding proteins (SREBPs) and steroid receptor coactivator-3 (SRC3) [9,11-15]. Given these substrates, it is perhaps unsurprising that Cdc4 has been shown to be a haplo-insufficient tumor suppressor gene [16]. This list of substrates also suggests that $\mathrm{Cdc} 4$ could regulate developmental events, and attempts to generate knockout mice led to an embryonic lethal phenotype [17]. We became interested in a role for $\mathrm{Cdc} 4$ during neural crest development in particular because several of its substrates have been implicated in the development of this tissue, for example, c-Myc and Notch intracellular domain $[18,19]$.

The neural crest is a unique population of cells, arising at the neural plate border in response to bone morphogenetic protein, Wnt and fibroblast growth factor signaling (for reviews, see [20,21]). Neural crest cells are initially multipotent, but subsequently undergo an epithelial to mesenchymal transition and migrate throughout the embryo, where they give rise to a wide range of derivatives (for reviews, see $[22,23]$ ). These include the neurons and glia of the peripheral nervous system, the autonomic nervous system, cartilage, bone, connective tissue, cardiac cells and melanocytes. The induction of the neural crest is often defined according to the expression of neural crest specifier genes, including the transcriptional repressors Snail2 and Snail $[24,25]$. A number of proteins involved in neural crest development display dynamic expression patterns, and it is becoming apparent that several are targets of the ubiquitin proteasome system. For example, Snail2 is degraded by the F-box protein Partner of paired (Ppa) [26].

Here we describe identification of the Xenopus laevis homologues of $\mathrm{Cdc} 4$, which are highly conserved at the sequence level, and are also functionally equivalent in terms of their ability to degrade Cyclin E. Two isoforms of Xenopus Cdc4 (xCdc4 $\alpha$ and $\mathrm{xCdc} 4 \beta$ ) are found to be dynamically expressed throughout early Xenopus development, with particular enrichment in neural crest and neural crest-derived tissues. Inhibition of $\mathrm{xCdc} 4$ activity, using dominant negative F-box mutants, blocks neural crest development, without affecting cell division or cell survival, nor affecting development of the other tissues in which they are expressed. Thus, Cdc4 directly and specifically regulates neural crest formation, independent of a previously described ability to regulate the cell cycle.

\section{Results \\ $X$. laevis encodes two isoforms of Cdc4: $x C d c 4 \alpha$ and $x \mathrm{Cdc} 4 \beta$}

The pseudotetraploid genome of $X$. laevis presents unique challenges to identifying genes reported in other model systems. In contrast, Xenopus tropicalis is possessed of a diploid genome, making it well suited for genetic manipulation and bioinformatic analysis. The existence of $X$. tropicalis and $X$. laevis in the same genus - therefore sharing a high level of evolutionary conservation between their respective genes - suggested to us a method of harnessing the sequenced genome of $X$. tropicalis to identify potential orthologs of human Cdc4 (hCdc4) present in X. laevis. BLAST of hCdc4 $\alpha$ (GenBank accession number AY049984) against the $X$. tropicalis genome revealed a sequence on scaffold 60:1694203-1694241 with strong nucleotide complementarity to the first exon of hCdc $4 \alpha$. Further downstream (scaffold 60:1696322-1,729,489) were exons 2 to 11 , whose sequence corresponded to the conserved regions found within hCdc4.

PCR primers targeting the identified $\mathrm{xCdc} 4$ sequence were used on oligo $d(T)$ primed mRNA derived from stage $20 \mathrm{X}$. laevis embryos. We performed 5' and 3' rapid amplification of cDNA ends (RACE) to isolate a full length product. Although slightly truncated, the protein was most similar to the $\beta$ isoform of hCdc4 and has been designated $\mathrm{xCdc} 4 \beta$ (Additional file 1). Analysis of the aligned regions demonstrates that $x \operatorname{Cdc} 4 \beta$ was $98 \%$ identical at the amino acid level and $83 \%$ identical at the nucleotide level to hCdc4 $\beta$. In comparison to other $X$. laevis F-box proteins, $\mathrm{xCdc} 4 \beta$ was $27 \%$ identical and $43 \%$ similar to $\beta$-TRCP ( $\beta$-Transducin repeat containing protein; GenBank accession number M98268) [27], and $17 \%$ identical and $20 \%$ similar to Skp2 (GenBank accession number DQ228920) [28].

A second isoform of $\mathrm{xCdc} 4$ was similarly cloned from stage $7 X$. laevis embryos (GenBank accession number DQ666345). Exon 1 was found on scaffold 60:16462931646793. Analysis demonstrated nearly perfect conservation at the amino acid level to the common set of exons, 2 to 11 , that occur in hCdc $4 \alpha$ and hCdc $4 \beta$ (data not shown). Additionally, the second identified $\mathrm{xCdc} 4$ contained an amino terminal exon most similar to the one present in human $\mathrm{Cdc} 4 \alpha$ and is referred to hereafter as $\mathrm{xCdc} 4 \alpha$. Furthermore, exon 1 of $\mathrm{xCdc} 4 \beta$ is spliced to the same downstream exons, 2 to 11 , used by $\mathrm{xCdc} 4 \alpha$. Alignment of their amino acid sequences showed strong conservation; differences in amino acid identity being 
conserved by use of residues with similar characteristics. Furthermore, both the isoform specific nuclear localization signal (amino acids 11 to 14) and common nuclear localization signal (amino acids 169 to 172) found in $\mathrm{hCdc} 4 \alpha$ are present in $\mathrm{xCdc} 4 \alpha$, which is suggestive of a similar pattern of localization and regulation [29].

From the region of the gene corresponding to the second exon, $x C d c 4 \alpha$ and $x \operatorname{xdc} 4 \beta$ are $99.8 \%$ identical (1,623 out of 1,626 nucleotides identical). A single amino acid substitution was made (changing Gly649 to Asp) to the $\mathrm{xCdc} 4 \alpha$ coding sequence used here, as this was conserved in all sequence orthologs. A $X$. laevis ortholog of hCdc $4 \gamma$ was not detected in either stage 7 or stage 20 embryos.

$x C d c 4 \alpha$ and $x C d c 4 \beta$ proteins are expressed throughout development, including prominent expression in the early neural crest

Next, the temporal expression of $\mathrm{xCdc} 4 \alpha$ and $\mathrm{xCdc} 4 \beta$ was examined during $X$. laevis development. Staged embryo lysates were separated by SDS PAGE and western blotted using antibodies to detect the two different isoforms, $\mathrm{xCdc} 4 \alpha$ and $\mathrm{xCdc} 4 \beta$. Anti-Cdc4 3B7 (referred to as anti-Cdc4 $\alpha$ ) detected both endogenous and in vitro translated $\mathrm{xCdc} 4 \alpha$ (Figure $1 \mathrm{~A}$ ). Although unable to detect endogenous levels of $\mathrm{xCdc} 4 \beta$, this antibody weakly detected overexpressed $\mathrm{xCdc} 4 \beta$ (data not shown). Anti-Cdc4 3A9 (referred to as anti-Cdc4 $\beta$ ) detected endogenous and in vitro translated $\mathrm{xCdc} 4 \beta$ (Figure 1B) Anti-Cdc4 $\beta$ also detected $\mathrm{xCdc} 4 \alpha$, although less effectively than anti-Cdc4 $\alpha$ (data not shown). Thus, western blotting demonstrates that both $\mathrm{xCdc} 4$ isoforms were expressed at all stages tested, from fertilized egg until stage 28 .

The spatial distribution of $\mathrm{xCdc} 4$ transcripts during $X$. laevis embryogenesis was also examined by in situ hybridization (ISH) using a probe that would recognize both isoforms of $\mathrm{xCdc} 4$. Prior to stage 15 , xCdc4 transcripts were expressed in a diffuse pattern in the ectoderm (data not shown). At stage 15, while more diffuse background staining remained, transcripts accumulated at the highest level in the neural crest, forming at the preplacodal ectoderm (Figure 1C, ppe) at the border of the epidermis and neural plate and in particular in the presumptive optic placode (Figure 1C, pop). At late neurula stages, $\mathrm{xCdc} 4$ transcripts are detected in the trunk (Figure 1D, E, TNc) and branchial neural crest (Figure 1D, b) as well as in the optic placode (Figure 1E, Opt P), and this staining pattern persists until stage 20 (Figure 1D, E). While continuing to be expressed in the neural crest derivatives (cranial neural crest (Cc) and branchial arches $(\mathrm{Ba})$ at later stages (Figure $1 \mathrm{~F}-\mathrm{G})$ ) $\mathrm{xCdc} 4$ was additionally expressed in the myotome (Figure 1G, H, My). From stage 26, staining of the posterior somites (s) and the neural crest-derived branchial arches
(Ba) persists, while staining in the fin mesenchyme (Fin), another neural crest-derived tissue, becomes prominent (Figure 1I-K). Expression in anterior placodes also becomes pronounced at stage 32 (Figure $1 \mathrm{~K}$, arrowheads). Staining was not observed with the sense control probe (Figure $1 \mathrm{~L}-\mathrm{N}$ ). In summary, $\mathrm{xCdc} 4$ transcripts were detected in the neural crest and placodes, neural crest-derived tissues, and additionally in the brain and somites. We compared the expression of $\mathrm{xCdc} 4$ with other markers of neural crest and placodes: Snail2 (also known as Slug), Snail, Sox10, Six1, Opl and Pax3 at stages $15 / 16,18 / 19,21 / 22,26 / 27$ and 32/33 [25,30-34] (Figures 2 and 3 ). At neurula and early tailbud stages, although $\mathrm{xCdc} 4$ shows a distinct expression pattern from each of these markers, its expression overlapped both in placodal regions and at the border of the epidermis and neural plate, where early neural crest arises (Figure 2). Similarly, at later stages $\mathrm{xCdc} 4$ expression in the branchial arches $(\mathrm{Ba})$, pharyngeal pouches $(\mathrm{Pp})$, cranial ganglia $(\mathrm{Cg})$ and olfactory placode (Olf $\mathrm{P}$ ) overlapped most significantly with the neural crest marker Snail and placodal marker Six1 (Figure 3).

Surface expression of $\mathrm{xCdc} 4$ was clear by whole mount ISH and was most prominent in neural crest and placodal regions. However, we saw less distinct staining more widely across the embryo and in other tissues, such as the myotome and potentially the neural tube (for example, Figure 1G), especially when the staining period was lengthened. Whole mount ISH is most suited to detect expression in tissues near to the embryo surface. To look more closely at $\mathrm{xCdc} 4$ expression in deep tissues, we performed ISH on sections. When allowing the ISHs to develop for 2 days, $\mathrm{xCdc} 4$ expression was seen throughout dorsal ectodermal and mesodermal tissue of the embryo, including in the neural plate/tube, epidermis, myotome and the notocord, with somewhat weaker staining in the epidermis (Figure 4A, B, G-I), while no staining was seen in the sense control (Figure $4 \mathrm{E}, \mathrm{F}, \mathrm{J}-\mathrm{L})$, demonstrating specificity. In agreement with our whole mount staining (Figure 1D), as the neural tube was closing, expression of $\mathrm{xCdc} 4$ appears strongest in areas lateral to the neural plate (Figure 4B) that also express Snail2 (Figure 4D), and so are developing neural crest. While other tissues also expressed $\mathrm{xCdc} 4$, staining of the neural crest was clear in all embryo sections examined (Figure 4A, B, G-I, arrows).

$\mathrm{xCdc} 4$ degrades Cyclin E and $\mathrm{xCdc} 4 \Delta \mathrm{Fbox}$ mutants act as dominant negatives

Mammalian Cdc4, and in particular Cdc4 $\alpha$, is known to target Cyclin $\mathrm{E}$ for ubiquitin-mediated proteolysis [35-38]. We wanted to determine whether $\mathrm{xCdc4}$ could target Cyclin $\mathrm{E}$ for degradation in $X$. laevis embryos, both by overexpressing the $\mathrm{xCdc} 4$ protein and by knocking out its function. To block $\mathrm{xCdc} 4$ function, we 
A

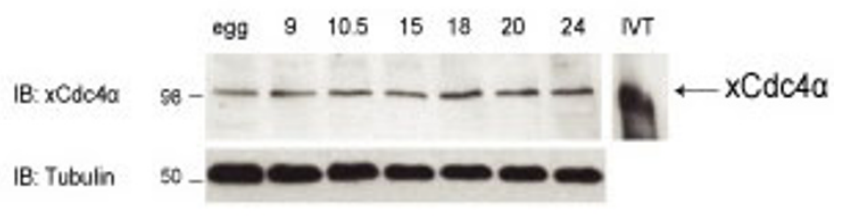

B
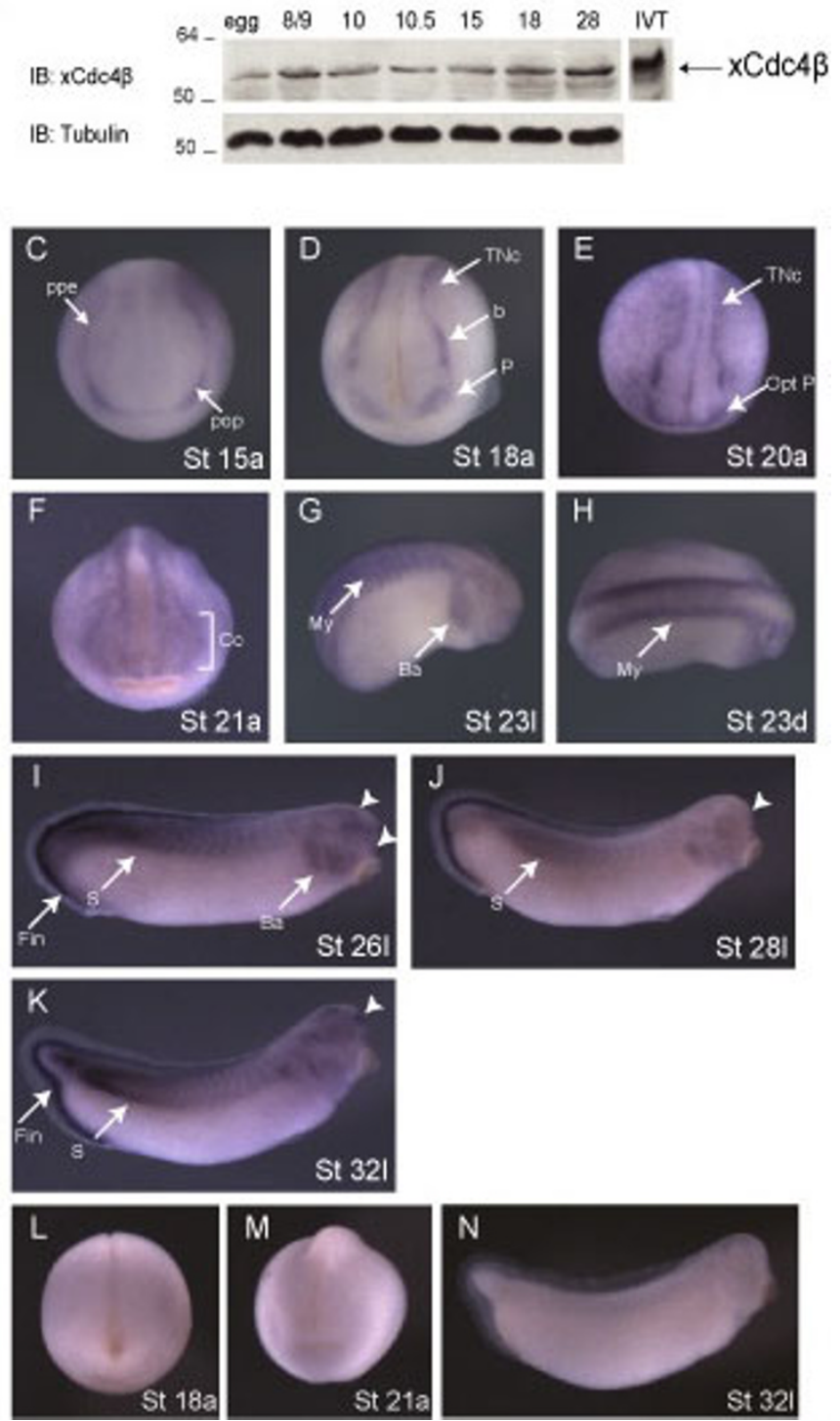

Figure $1 \times \mathrm{xdc} 4 \alpha$ and $\mathrm{xCdc} 4 \beta$ protein are expressed throughout development, and transcripts accumulate in the neural crest and neural crest derived tissues. Expression of (A) $\times C d c 4 \alpha$ and (B) $\times C d c 4 \beta$ in staged embryo lysates was determined by immunoblotting (IB) using anti-Cdc4 antibodies. In vitro translated (IVT) protein was used as a control. Equal loading was verified by IB for tubulin, with the equivalent of one embryo per lane loaded. (C-K) Developmental expression of xCdc4 was determined by whole mount ISH. At stage 15 (C), xCdc4 expression is detected broadly at the preplacodal ectoderm (ppe), in particular in the presumptive optic placode (pop) as well as in the prospective trunk neural crest (TNc). At late neurula stages $(\mathrm{D}, \mathrm{E})$, while $\mathrm{xCdc4}$ transcripts continue accumulating in the trunk neural crest and optic placode (Opt P), xCdc4 is also detected in the cranial neural crest, particularly within the branchial aggregates (b). At stage $21(\mathrm{~F}), x \mathrm{Cdc4}$ is broadly detected in migrating cranial neural crest $(\mathrm{Cc})$ and placodal regions. At stage $23(\mathrm{G}, \mathrm{H}), \times \mathrm{Cdc} 4$ is expressed in cranial neural crest that populates the branchial arches (Ba) and additionally in the myotome (My). At stage $26(\mathrm{I}), \mathrm{xCdc4}$ continues to be expressed in the myotome and branchial arches, as well as in several anterior placodes (arrowheads). xCdc4 is additionally expressed in the posterior fin mesenchyme (Fin). From stage 28 to $32(J, K)$, xCdc4 expression is downregulated in the branchial arches, while persisting in the anterior placodal region (arrowheads), dorsal somites (s) and dorsal and ventral fin mesenchyme (Fin). Whole mount ISH at the indicated stages using $x C d c 4 \beta$ sense probe confirms the specificity of the probe (L-N). Views in (C-N) are indicated bottom right after the stage (St): a, anterior view; d, dorsal view; l, lateral view. 


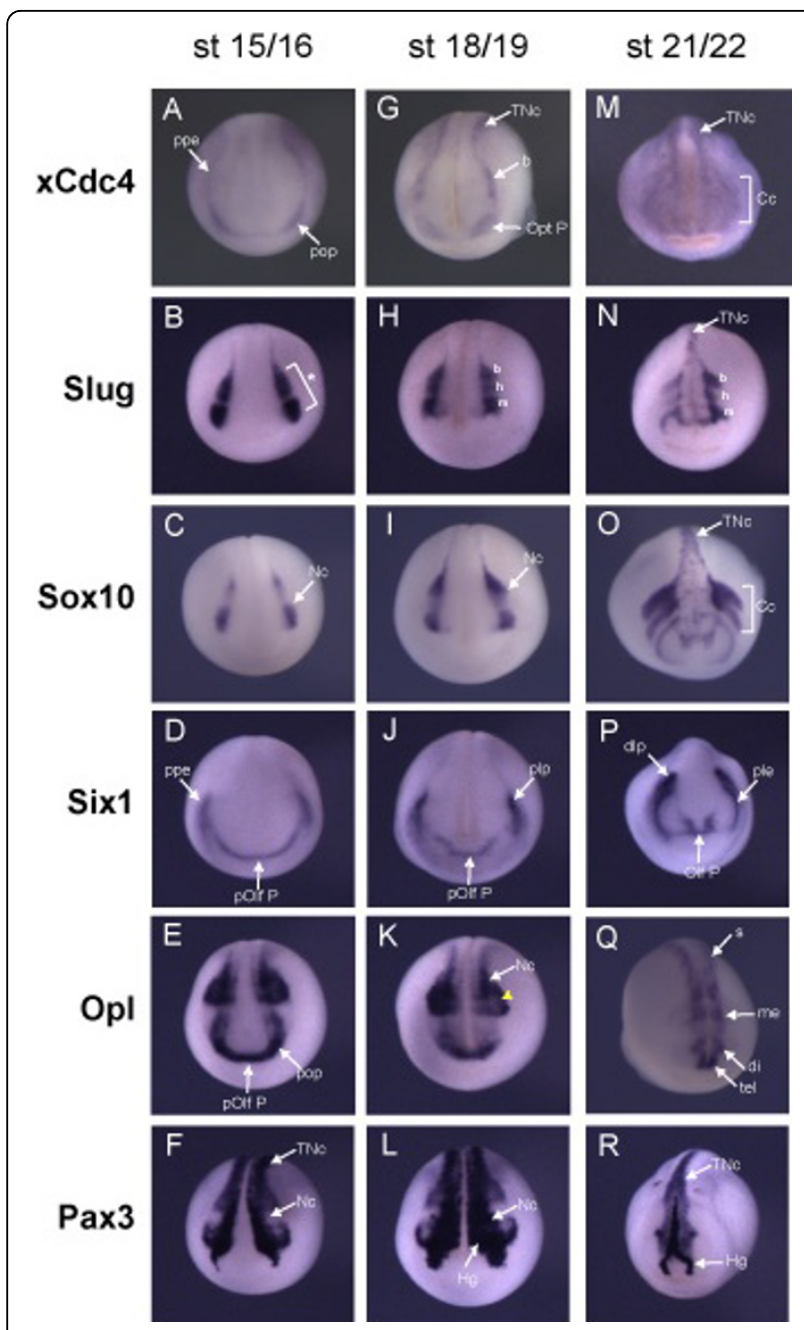

Figure $2 \times C d c 4$ expression overlaps with expression of markers of neural crest and placodes. (A-R) Comparison of $x \mathrm{Cdc} 4$ developmental expression $(A, G, M)$ with the expression of neural crest and placodal gene markers in stage 15/16 (B-F), 18/19 (H-L) and 21/22 (N-R) embryos, as labeled. Asterisk indicates premigratory cranial crest; b, branchial crest; Cc, cranial neural crest; di, diencephalons; dlp, dorsolateral placodal area; $\mathrm{Hg}$, hatching gland; $h$, hyoid crest; $m$, mandibular crest; me, mesencephalon; Nc, neural crest; Olf $\mathrm{P}$, olfactory placode; Opt $\mathrm{P}$, optic placode; plp, presumptive lens placode; pOlf $\mathrm{P}$, presumptive olfactory placode; ppe, preplacodal ectoderm; pop, presumptive optic placode; $s$, somites; tel, telencephalon; TNc, trunk neural crest; yellow arrowhead, neural plate border region of the prospective rhombencephalon. Anterior view, dorsal up, stages as indicated.

initially tried to prevent translation of $\mathrm{xCdc} 4 \mathrm{mRNAs}$ by microinjection of antisense morpholino oligonucleotides. Although xCdc4-directed morpholinos specifically inhibited translation of synthetic mRNA encoding $\mathrm{xCdc} 4 \alpha$ or $\mathrm{xCdc} 4 \beta$, demonstrating their functionality, microinjection into embryos had only a small effect on $\mathrm{xCdc} 4 \alpha$ protein levels and no detectable effect on $\mathrm{xCdc} 4 \beta$ levels, as detected by western blot (data not shown).

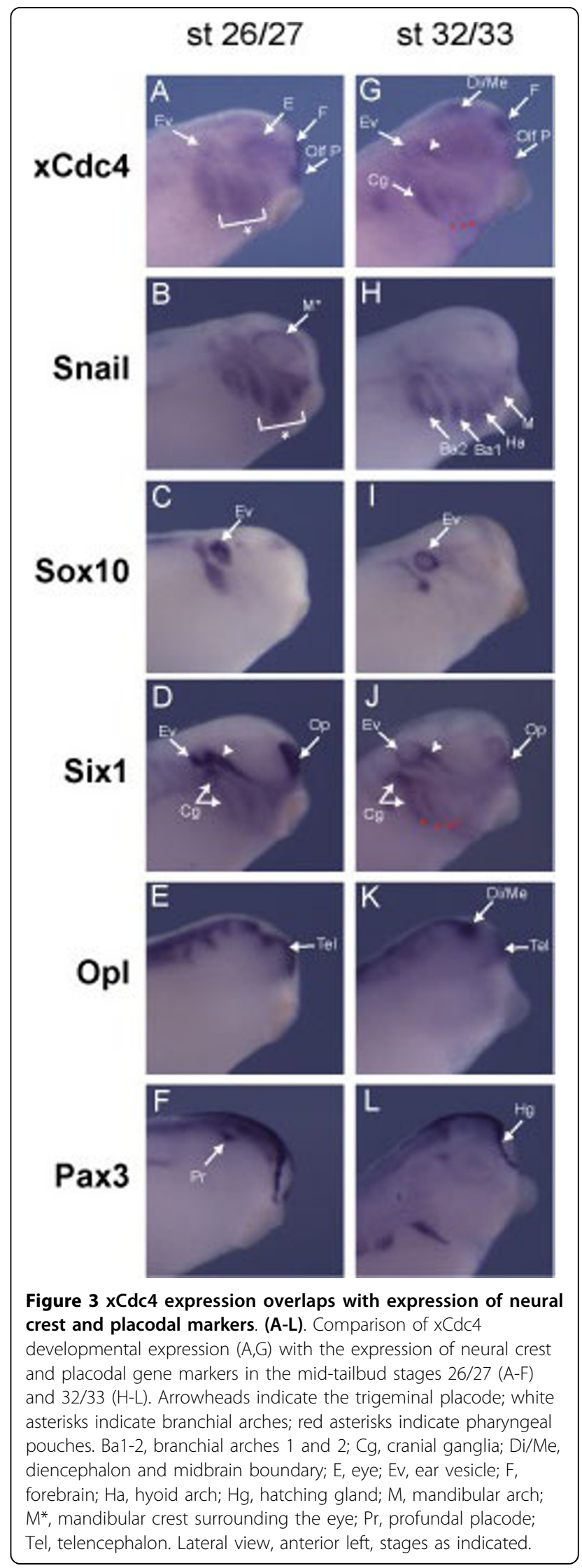




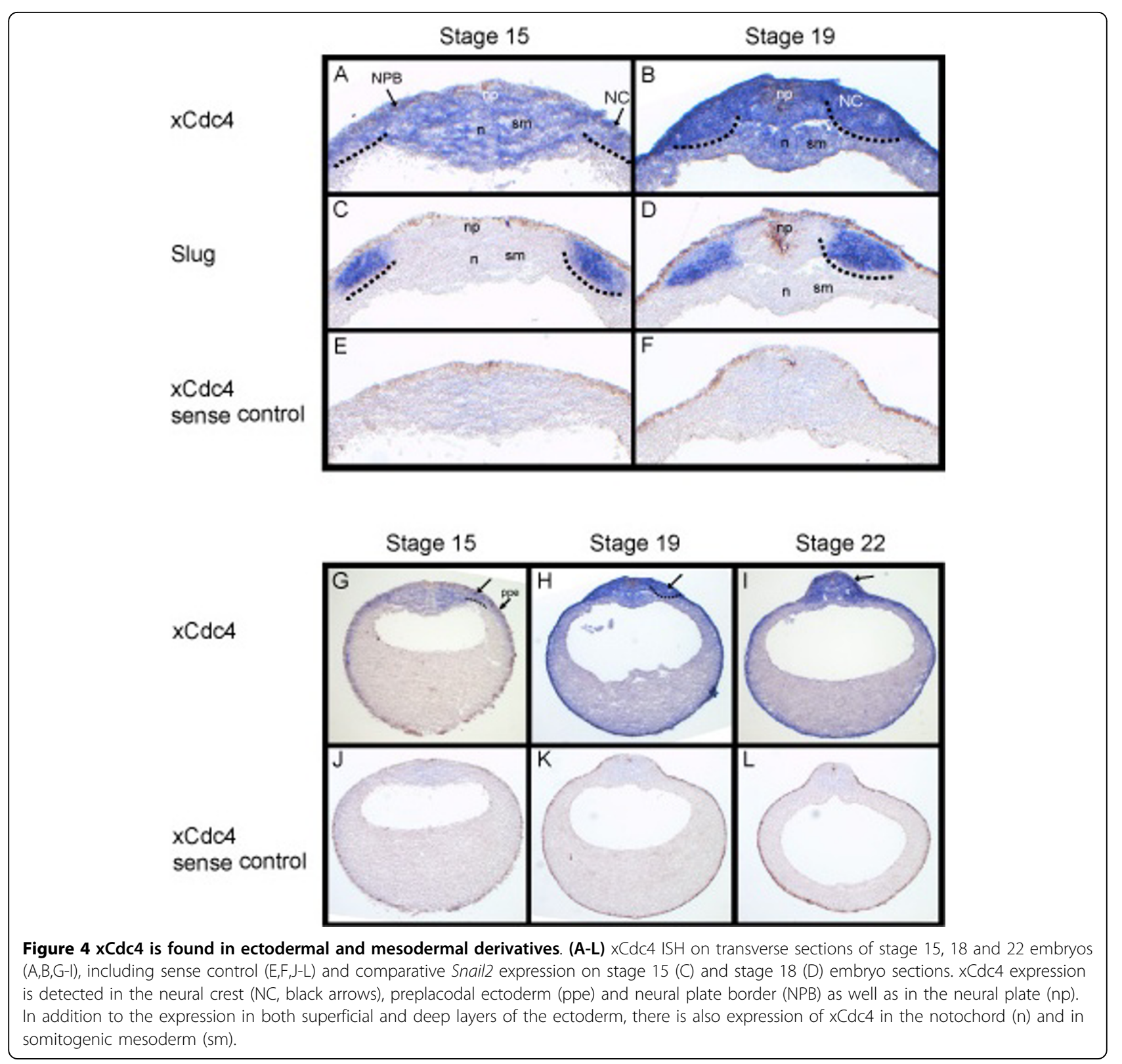

Morpholinos are only effective when protein levels depend on new translation of mRNAs. Our developmental western blot (Figure 1A, B) indicated that both $\mathrm{xCdc} 4 \alpha$ and $\mathrm{xCdc} 4 \beta$ are supplied in the egg as maternal stockpiles, and these would not be affected by this antisense strategy.

$\mathrm{xCdc} 4$ is a member of the F-box E3 ligase family, and as such, requires an intact F-box to interact with the rest of the SCF complex to target proteins for proteolysis. Deletion of the F-box allows substrate binding but prevents recruitment to the ubiquitination machinery, and this strategy has been successfully used many times to create a dominant negative construct (for example, $[9,39])$, whose overexpression results in specific substrate hyper-stability. Therefore, we used an F-box deleted dominant negative form of $\mathrm{xCdc} 4$ to block the function of endogenous $\mathrm{xCdc} 4$ protein.

Cyclin E overexpression in X. laevis embryos results in a loss of DNA at early cleavage stages. This leads to a reduction in the rate of cell cleavage, followed by apoptosis of the affected cells at mid-gastrulation [40]. To determine whether $\mathrm{xCdc} 4 \alpha$ and $\mathrm{xCdc} 4 \beta$ could both act as E3 ligases for Cyclin E in vivo, and to demonstrate that $\mathrm{xCdc} 4 \Delta \mathrm{Fbox}$ has lost this activity, we compared their ability to inhibit Cyclin E-mediated apoptosis after micro-injection into $X$. laevis embryos, as compared with the anti-apoptotic protein BclXL. As expected, injection of Cyclin $\mathrm{E}$ either alone or with green 
fluorescent protein (GFP) mRNA resulted in a slowing of blastomere cleavage detectable at stage 9 , followed by apoptosis at mid-gastrulation stage 11 (Figure 5B, H). Co-injection of Cyclin E and BclXL resulted in the appearance of larger blastomeres, but these failed to undergo apoptosis later, as expected (Figure 5E, K). Injection of both $\mathrm{xCdc} 4 \alpha$ and $\mathrm{xCdc} 4 \beta$ along with Cyclin $E$ suppressed the number of embryos with enlarged cells and largely prevented apoptosis (Figure 5A, C, D, I, J), while $\mathrm{xCdc} 4 \alpha \Delta$ Fbox and $\mathrm{xCdc} 4 \beta \Delta$ Fbox proteins were ineffective at suppressing these phenotypes (Figure 5A, $\mathrm{F}, \mathrm{G}, \mathrm{L}, \mathrm{M})$. Thus, $\mathrm{xCdc} 4 \alpha$ and $\mathrm{xCdc} 4 \beta$ can act as $\mathrm{E} 3$ ligases in vivo when overexpressed and require the $\mathrm{F}$ box for this function.

Cdc4 is thought to target only a phosphoform of Cyclin E for destruction [35-38]. To look directly at the effect of $\mathrm{xCdc} 4$ on degradation of Cyclin $\mathrm{E}$ protein by western blot, $1 \mathrm{ng}$ of RNA encoding amino-terminal FLAG Cyclin E was injected into fertilized eggs along with mRNAs encoding $\mathrm{xCdc} 4$ (using the $\alpha$ isoform) or GFP, as an injection control (Figure 6), and embryos were allowed to develop to stage 10.5. Embryo lysates were prepared and immunoblotting was performed to detect the FLAG epitope on Cyclin E.

Cyclin E migrated as multiple bands in GFP-injected embryos (Figure 6A, lane 2), and these are likely to be phospho-forms of the protein [41]. When co-injected with Cyclin E mRNA, $\mathrm{xCdc} 4$ expression resulted in a reduction in the abundance of predominantly the slower-migrating phospho-forms of Cyclin E protein (Figure 6A, lane 3). Densitometry analysis, normalizing to actin expression in the same samples, confirmed that phosphorylated forms of Cyclin E are degraded by $\mathrm{xCdc} 4$. This is in agreement with previous results, which demonstrated a requirement for Cyclin E phosphorylation to direct Cdc4-mediated degradation $[9,38,42]$. These results verify that $\mathrm{xCdc} 4$ is functionally orthologous to mammalian Cdc4 in its ability to degrade phospho-forms of Cyclin E.

To confirm that the F-box deletion mutant of $\mathrm{xCdc} 4$ (xCdc4 $\Delta$ Fbox) possessed dominant negative activity, its ability to inhibit Cyclin E degradation mediated by wildtype $\mathrm{xCdc} 4$ was assessed. Cyclin E mRNA was coinjected with $\mathrm{xCdc} 4$ along with one of the following: $\mathrm{xCdc} 4 \Delta$ Fbox, $\mathrm{xSkp} 2 \Delta \mathrm{Fbox}$, an F-box mutant of the related SCF E3 ligase Skp2, or GFP (Figure 6A, lanes 2 to 5). As expected, overexpression of either $\mathrm{xSkp} 2 \Delta \mathrm{Fbox}$ or GFP had no effect on phospho-Cyclin E degradation by $\mathrm{xCdc} 4$. In contrast, degradation of Cyclin $\mathrm{E}$ by $\mathrm{xCdc} 4$ was inhibited by co-injection of $\mathrm{xCdc} 4 \Delta$ Fbox (lane 5), confirming that this mutant acts as a dominant negative form of $\mathrm{xCdc} 4$ in the embryos. When phospho-Cyclin $\mathrm{E}$ levels were normalized to the levels in embryos injected with Cyclin E and GFP, xCdc4 and GFP co-injection led
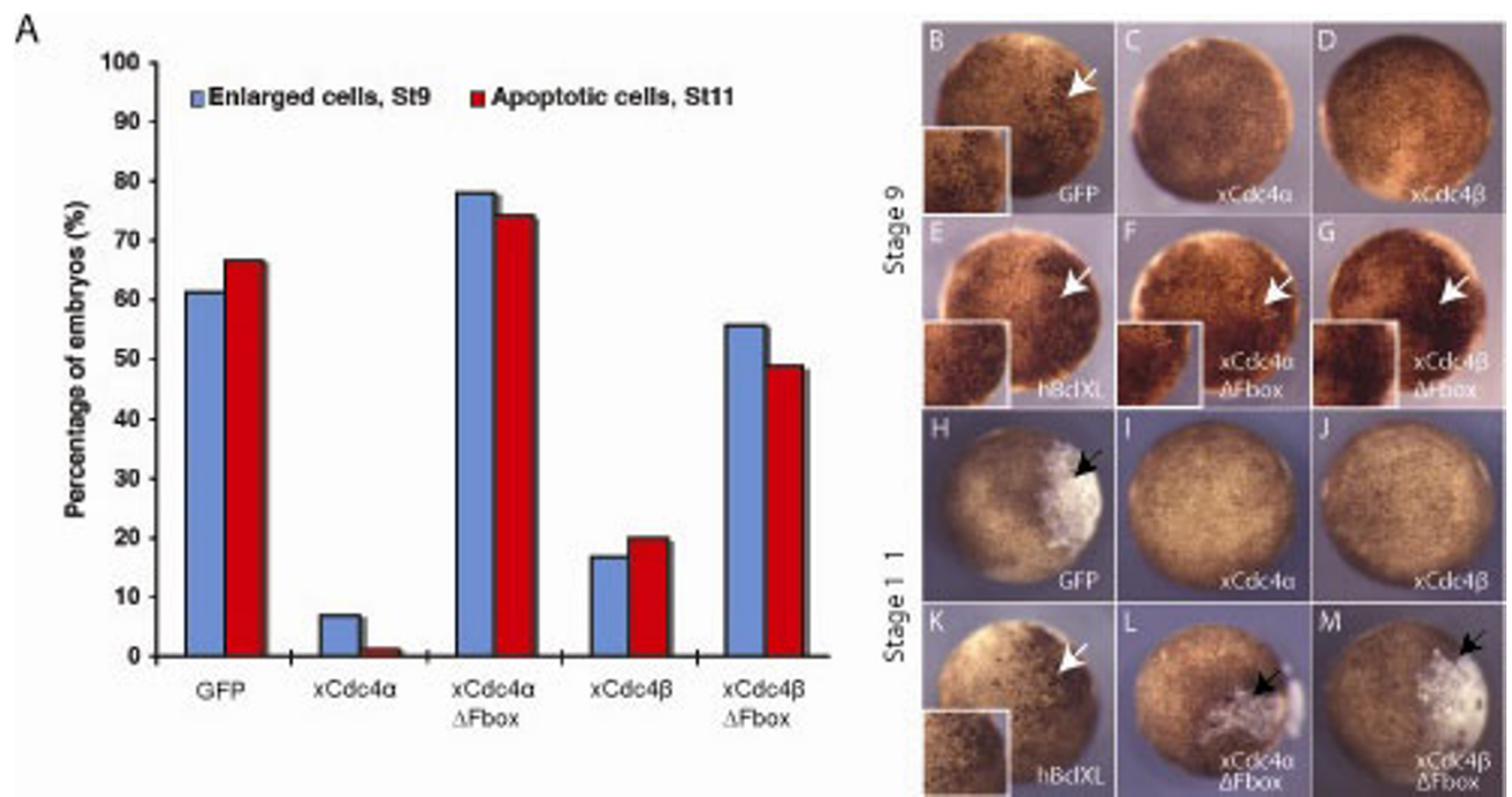

Figure $5 \times \mathrm{Cdc} 4 \alpha$ and $x \mathrm{Cdc} 4 \beta$ block Cyclin E-mediated apoptosis, and this requires an intact F-box domain. Cyclin E mRNA (1 ng) was co-injected with $1 \mathrm{ng}$ of other mRNAs as indicated into one cell of two-cell-stage embryos. (A) Embryos were scored for enlarged cells at stage 9 and apoptotic cells at stage $11(n=75-196)$. (B-M) Representative embryos from each injection are shown; enlarged cells are highlighted with white arrows (B,E-G,K) and shown enlarged in insets. Black arrows highlight apoptotic cells (H,L,M). 


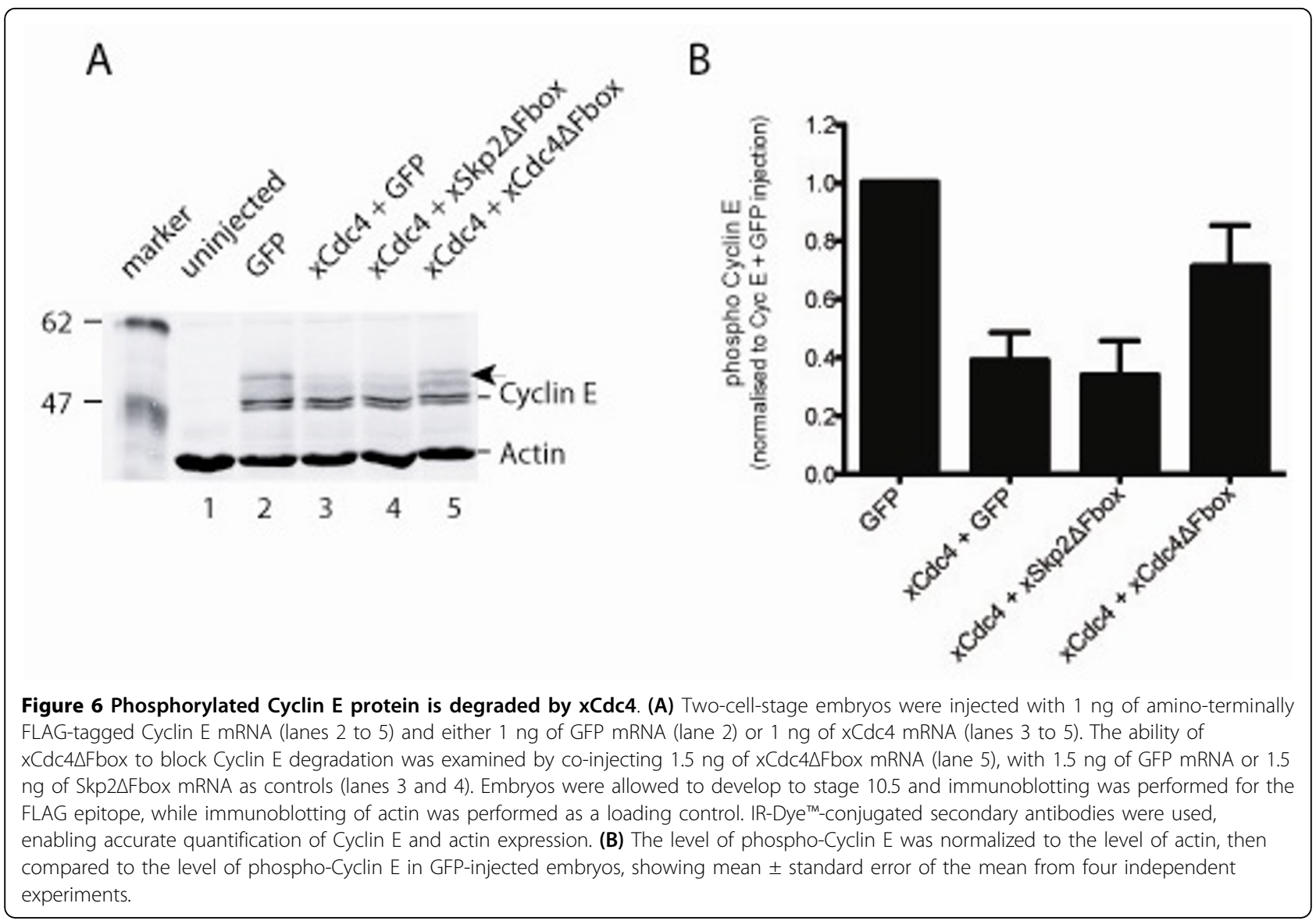

to a $60 \%$ reduction in Cyclin E levels (Figure 6B). When $\mathrm{xCdc} 4$ was co-injected with $\mathrm{xSkp} 2 \Delta$ Fbox, a similar reduction in Cyclin E levels was observed (70\%). However, coexpression of $\mathrm{xCdc} 4 \Delta \mathrm{Fbox}$ with $\mathrm{xCdc} 4$ partially rescued the degradation of Cyclin E. On average, there was a $30 \%$ reduction in Cyclin E levels compared to Cyclin E- and GFP-injected embryos. In addition, we also found that $\mathrm{xCdc} 4$ targeted endogenous Cyclin $\mathrm{E}$ for degradation (data not shown), again predominantly reducing the slower-migrating phospho-form of the protein.

At these early developmental stages, Cyclin $\mathrm{E}$ is expressed throughout the ectoderm [43], so may act as a target for $\mathrm{xCdc} 4$. Since $\mathrm{Cdc} 4$ is known to regulate the stability of other proteins that regulate cell proliferation (for a review, see [10]), we investigated whether $\mathrm{xCdc} 4$ modulated cell cycle progression in the early embryo. As $x C d c 4 \alpha$ and $x C d c 4 \beta$ share the same substrate binding regions, $\mathrm{xCdc} 4 \beta \Delta$ Fbox (hereafter known as $\mathrm{xCdc} 4 \Delta$ Fbox) would be expected to inhibit the activity of both $\mathrm{xCdc} 4$ isoforms, and was used throughout in this study. Indeed, $\mathrm{xCdc} 4 \alpha \Delta$ Fbox gave similar results to $\mathrm{xCdc} 4 \beta \Delta$ Fbox (data not shown). $x C d c 4 \Delta$ Fbox does not affect cell cycle in the embryonic ectoderm

To investigate the effect of $\mathrm{xCdc} 4$ activity on cell proliferation, mRNA encoding $\mathrm{xCdc} 4 \beta$ or $\mathrm{xCdc} 4 \Delta$ Fbox was injected unilaterally into two-cell-stage embryos with GFP mRNA injected as a control. Whole mount staining using an antibody against phosphorylated histone $\mathrm{H} 3$ (phH3) was used to examine the number of mitotic cells [44]. No change in the number of mitotic cells in the neural folds was observed following overexpression of $\mathrm{xCdc} 4 \Delta$ Fbox or $\mathrm{xCdc} 4$ (Figure 7 ). To quantify this, the number of mitotic cells in the neural folds was counted on the injected and uninjected sides, and the percentage difference was calculated for each embryo. The average percentage change for $\mathrm{xCdc} 4 \Delta$ Fbox $(-2.8 \pm 3.9 \%)$ and $\mathrm{xCdc} 4(-9 \pm 1.2 \%)$ overexpression was not significantly different from that found after GFP overexpression $(-8.3 \pm 1.5 \%, \mathrm{n}=84$ to 91). Therefore, overexpression of $x C d c 4 \Delta$ Fbox did not perturb the cell cycle. Indeed, we saw no difference in the size of the blastomeres on the injected versus the uninjected side of the embryo (data not shown and Figure 7), confirming this conclusion. 


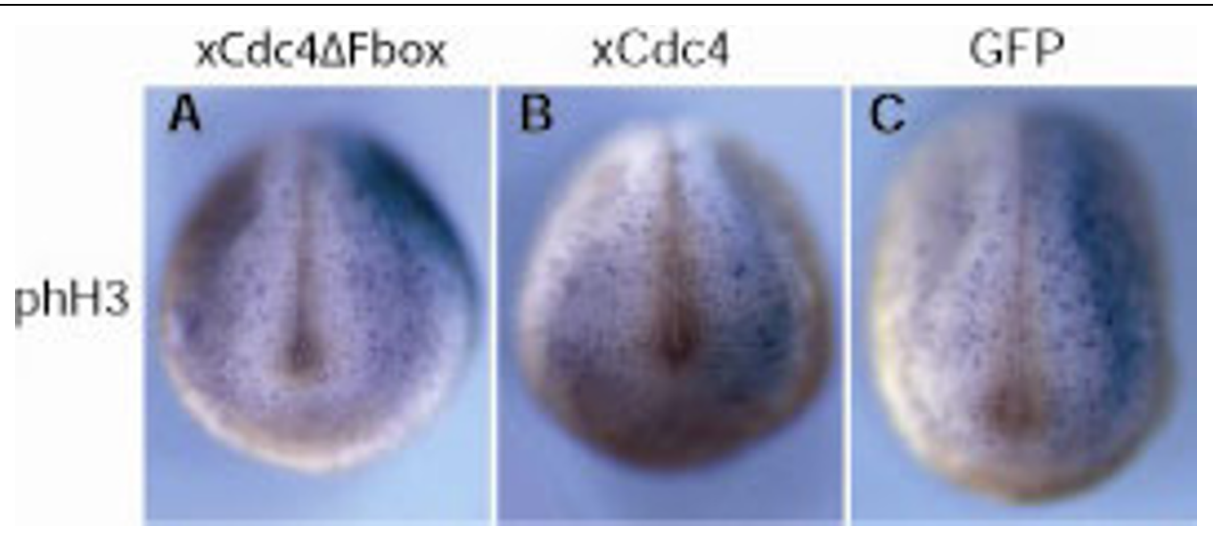

Figure $7 \times \mathrm{xCdc} 4 \Delta$ Fbox does not affect the cell cycle. $x C d c 4 \Delta F b o x$ or $x C d c 4$ mRNA (1 ng) was injected into one cell of two-cell-stage embryos. GFP mRNA (1 ng) was injected as a control, and $\beta$-gal mRNA was injected as a lineage tracer (light blue unilateral staining). Whole mount antibody staining against phH3 was performed to detect mitotic cells. The average percentage difference in the number of mitotic cells on the injected side, compared to the uninjected side, was calculated as indicated in Materials and methods. Representative embryos are shown (anterior view, dorsal up, injected side right).

\section{$x C d c 4 \Delta$ Fbox inhibits neural crest development}

$\mathrm{xCdc} 4$ is expressed prominently in the neural crest throughout early development (Figures 1 and 2). In order to examine the effect of inhibition of $\mathrm{xCdc} 4$ on neural crest development, $\mathrm{xCdc} 4 \Delta$ Fbox was overexpressed in developing embryos and compared to $\mathrm{xCdc} 4$ and GFP injections as controls. After injection of mRNAs into one cell of two-cell embryos, and subsequent development to neural plate stage 15, whole mount ISH for the neural crest markers Snail2, Snail and $c-M y c$ were performed. Overexpression of $\mathrm{xCdc} 4 \Delta$ Fbox inhibited formation of the neural crest as measured by decreased Snail2 and Snail expression (Figure $8 \mathrm{~A}, \mathrm{D}$ ), while wild-type $\mathrm{xCdc} 4$ and GFP had very little effect (Figure $8 \mathrm{~B}, \mathrm{C}, \mathrm{E}, \mathrm{F}$ ). In addition, $c-M y c$, a very early marker of neural crest [28], was also reduced by $\mathrm{xCdc} 4 \Delta$ Fbox (Figure $8 \mathrm{G}$ ), but not by $\mathrm{xCdc} 4$ or GFP (Figure $8 \mathrm{H}, \mathrm{I}$ ).

To quantify the reduction in expression of neural crest markers brought about by overexpression of $\mathrm{xCdc} 4 \Delta$ Fbox, the area of staining of Snail2, Snail and $c$ $M y c$ on the injected side of each embryo was measured and expressed as a ratio of the area on the uninjected side. A ratio less than 1 indicated a reduction in staining on the injected side compared to the uninjected side. The mean ratio was then calculated for at least two independent experiments, and compared with the ratio for GFP-injected embryos (which had minimal effect).

Overexpression of $\mathrm{xCdc} 4 \Delta \mathrm{Fbox}$ blocked neural crest development, as determined by expression of Snail2, Snail and $c-M y c$, resulting in an average $57 \%$ reduction in Snail2 staining on the injected side of the embryo, compared with embryos injected with GFP alone. Overexpression of $\mathrm{xCdc} 4$ had essentially no effect on Snail2 staining ( $\mathrm{n}=58$ to 122 ). Similarly, overexpression of
$\mathrm{xCdc} 4 \Delta$ Fbox reduced Snail and $c-M y c$ staining on the injected side of the embryo by $80 \%$ and $67 \%$ respectively, when compared to embryos injected with GFP alone ( $\mathrm{n}=30$ to 52 for both).

To confirm that $\mathrm{xCdc} 4 \Delta$ Fbox was acting as a dominant negative, we determined whether co-injection with wild-type $\mathrm{xCdc} 4$ could rescue the reduction in neural crest. In this experiment, $\mathrm{xCdc} 4 \Delta$ Fbox significantly reduced Snail2 and Snail expression in 34\% and 67\% of embryos, respectively, compared to only $12 \%$ and $6 \%$, respectively, when the wild-type $\mathrm{xCdc} 4$ was co-injected with $\mathrm{xCdc} 4 \Delta$ Fbox ( $\mathrm{n}=18$ to 21; Figure 9). This rescue demonstrates that $\mathrm{xCdc} 4 \Delta$ Fbox can act as a dominant negative in the presence of wild-type $\mathrm{xCdc} 4$. Indeed, as endogenous $\mathrm{xCdc} 4$ is likely to be expressed at a much lower concentration than that expressed from microinjected mRNA, $x C d c 4 \Delta$ Fbox is likely to be much more effective at inhibiting the endogenous $\mathrm{xCdc} 4$ protein.

As our sections revealed rather broad expression of $\mathrm{xCdc} 4$ in ectodermal and mesodermal derivatives, we investigated whether $\mathrm{xCdc} 4 \Delta$ Fbox affected patterning and/or specification of other tissues. We saw that anterior-posterior patterning and mesoderm development of the embryos were unaffected by overexpression of either wild-type $\mathrm{xCdc} 4$ or $\mathrm{xCdc} 4 \Delta$ Fbox, as determined by Otx2, Engrailed2, Krox20, MyoD, Heavy chain myosin $(H C M)$ and epidermal keratin expression (Additional files 2 and 3). Moreover, Sox2, a marker of neural plate neuronal precursors, and Neural beta-tubulin $(N \beta T)$, a marker of neuronal differentiation, were also unaffected (Figure 8S; Additional file 3). This suggested that the effect of $x C d c 4 \Delta$ Fbox overexpression on neural crest development was not dependent on either early patterning events or secondary effects resulting from induction of mesoderm, and was indeed specific to the neural 


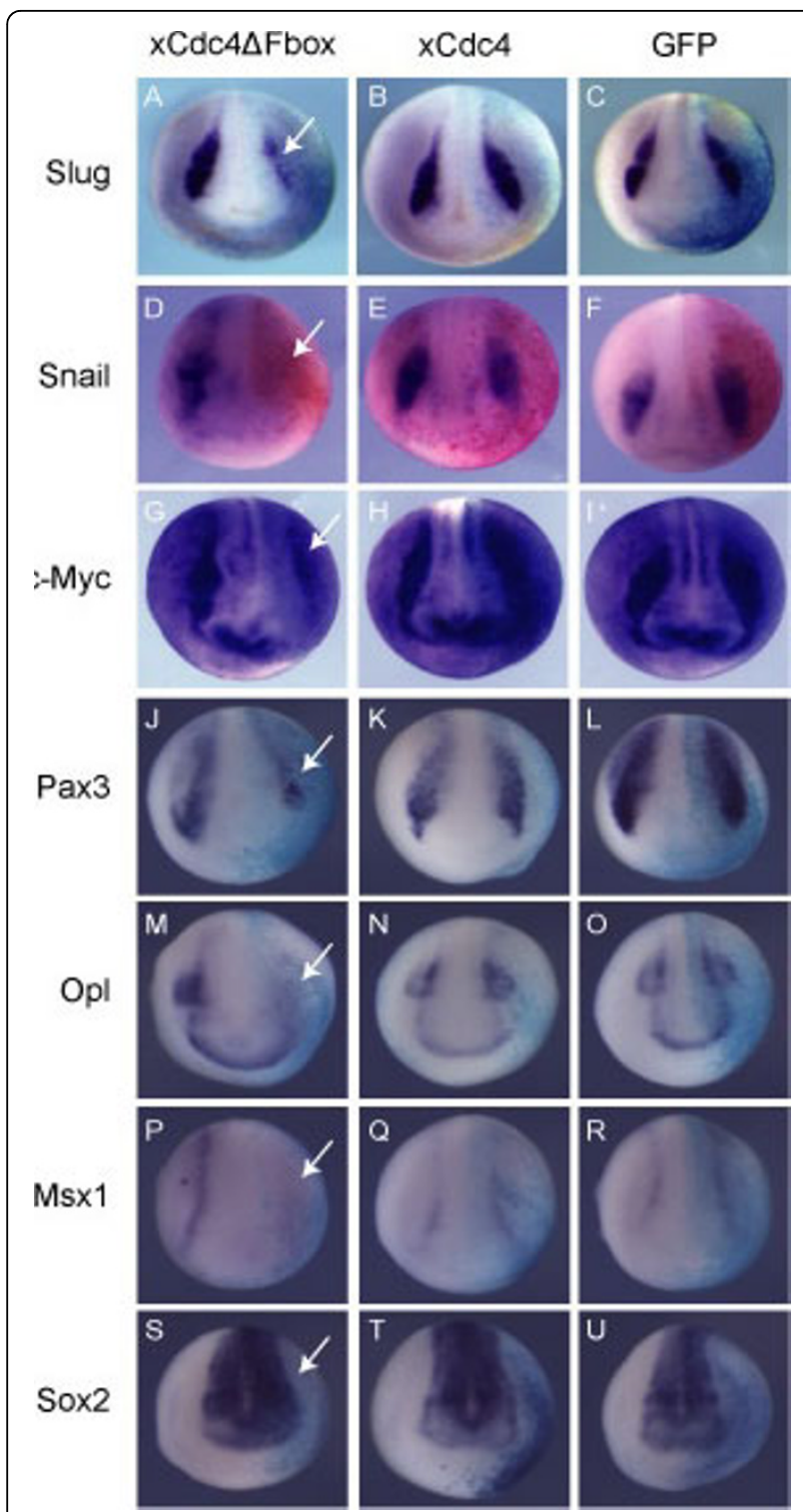

Figure $8 \times C$ dc $4 \Delta$ Fbox inhibits neural crest development $x C d c 4 \Delta$ Fbox or xCdc4 mRNA (1 ng) was injected into one cell of two-cell-stage embryos. GFP mRNA (1 ng) was injected as a control, and $\beta$-gal mRNA was injected as a lineage tracer (light blue or red unilateral staining). (A-U) Whole mount ISH was performed for Snail2 (A-C), Snail (D-F), C-Myc (G-I), Pax3 (J-L), Opl (M-O) and Msx1 $(P-R)$, and the early neuronal marker Sox2 (S-U). Representative embryos are shown (anterior view, dorsal up, injected side right).

crest. This effect is also specific to $\mathrm{xCdc} 4 \Delta \mathrm{Fbox}$; the Skp2 $\Delta$ Fbox mutant had no effect on Snail2 expression (Additional file 4).

We investigated whether $\mathrm{xCdc} 4$ activity was required for expression of other regulators of neural crest formation lying upstream of Snail2 and Snail (Figure 8). At stage 15, Pax3 (53\%) and Msx1 (100\%) showed significant reduction in the presence of $\mathrm{xCdc} 4 \Delta$ Fbox but not wild-type $\mathrm{xCdc} 4$, indicating that $\mathrm{xCdc} 4$ plays a broad role in controlling expression of regulators of neural crest. Interestingly, $\mathrm{xCdc} 4 \Delta$ Fbox inhibited neural crest expression of $\mathrm{Opl}$ in some embryos (62\%), but did not have a significant effect on its placodal expression (Figure $8 \mathrm{M})$. This is supported by the failure of $\mathrm{xCdc} 4 \Delta$ Fbox to affect the expression of the placodal marker Six1 (Additional file 5). Thus, xCdc4 does not play an essential role in specification of all the tissues in which it is expressed, but does have an essential role in formation of the neural crest.

$\mathrm{xCdc} 4$ is expressed broadly and diffusely before stage 15 , and while expression is seen in other tissues, transcripts concentrate in the placodes and neural crest derivatives as the neural tube closes (Figures 1, 2, and 4). The first signs of neural crest specification occur earlier, so we investigated whether $\mathrm{xCdc} 4$ was required for establishment or maintenance of neural crest identity. To this end, we investigated the effect of $\mathrm{xCdc} 4 \Delta \mathrm{Fbox}$ expression on earlier marker expression in the prospective neural crest (Figure 10). After overexpression of $\mathrm{xCdc} 4 \Delta$ Fbox, we saw a reduction in Snail2 $(44 \%$; $\mathrm{n}=$ $32)$ and Snail $(58 \% ; \mathrm{n}=26)$ expression by stage $13 / 14$ that was not seen with the wild-type protein (both $100 \%$ no significant reduction; $\mathrm{n}=25$ and $\mathrm{n}=35$, respectively), indicating that $\mathrm{xCdc} 4$ has a role early in neural crest specification, and is not solely required for its maintenance.

To determine the effect of inhibiting $\mathrm{xCdc} 4$ on later neural crest derivatives, we allowed embryos injected in both dorsal cells of four-cell-stage embryos to develop until stage 43 , and then investigated the differentiation of melanocytes and formation of cartilage, both neural crest-derived tissues. We saw that embryos injected with GFP had a normal number and distribution of melanocytes. In contrast, after injection of $\mathrm{xCdc} 4 \Delta \mathrm{Fbox}$, embryos showed significant reduction and an abnormal distribution of melanocytes (Figure $11 ; \mathrm{n}=31$ to $57, P$ $<0.0001)$ ) compared with the GFP-injected controls. A much smaller decrease in the number of melanocytes was also observed following injection with $\mathrm{xCdc} 4$ when compared with the GFP control $(P<0.01)$. As $\mathrm{xCdc} 4 \Delta$ Fbox-injected embryos looked abnormal, with a significant reduction of head morphology, we examined the effect of $x C d c 4 \Delta$ Fbox on cartilage formation by staining the embryos with alcian blue. We found that most $\mathrm{xCdc} 4 \Delta$ Fbox-injected embryos showed compacted head cartilage with weaker cartilage staining compared to xCdc4- or GFP-injected embryos (data not shown).

We also noted that embryos that were expressing $\mathrm{xCdc} 4 \Delta$ Fbox show other developmental abnormalities, including oedema and a high frequency of reduced eyes (Figure 11A). These phenotypes, which we have not been characterized further, may be secondary to loss of neural crest or may result from a later requirement of 

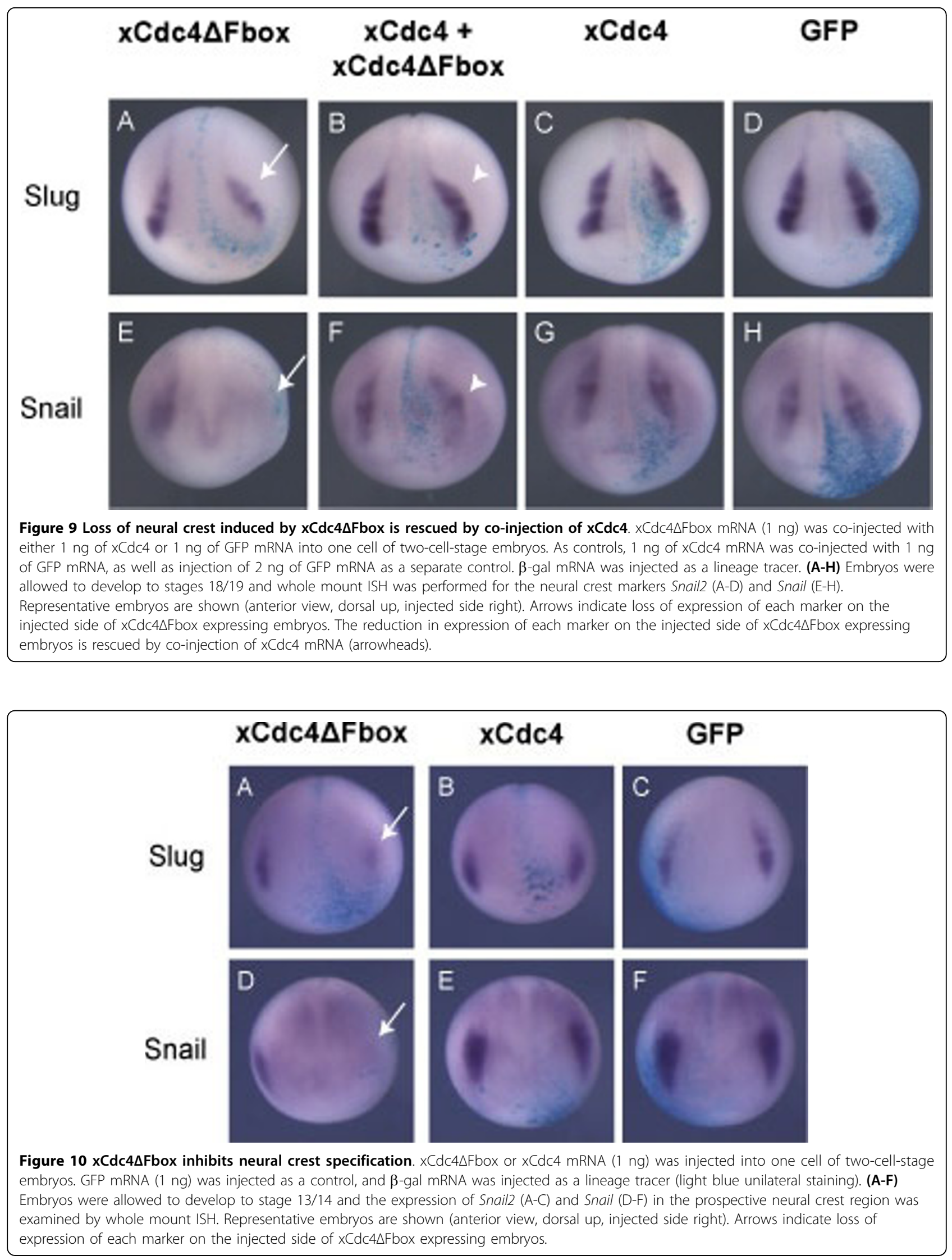


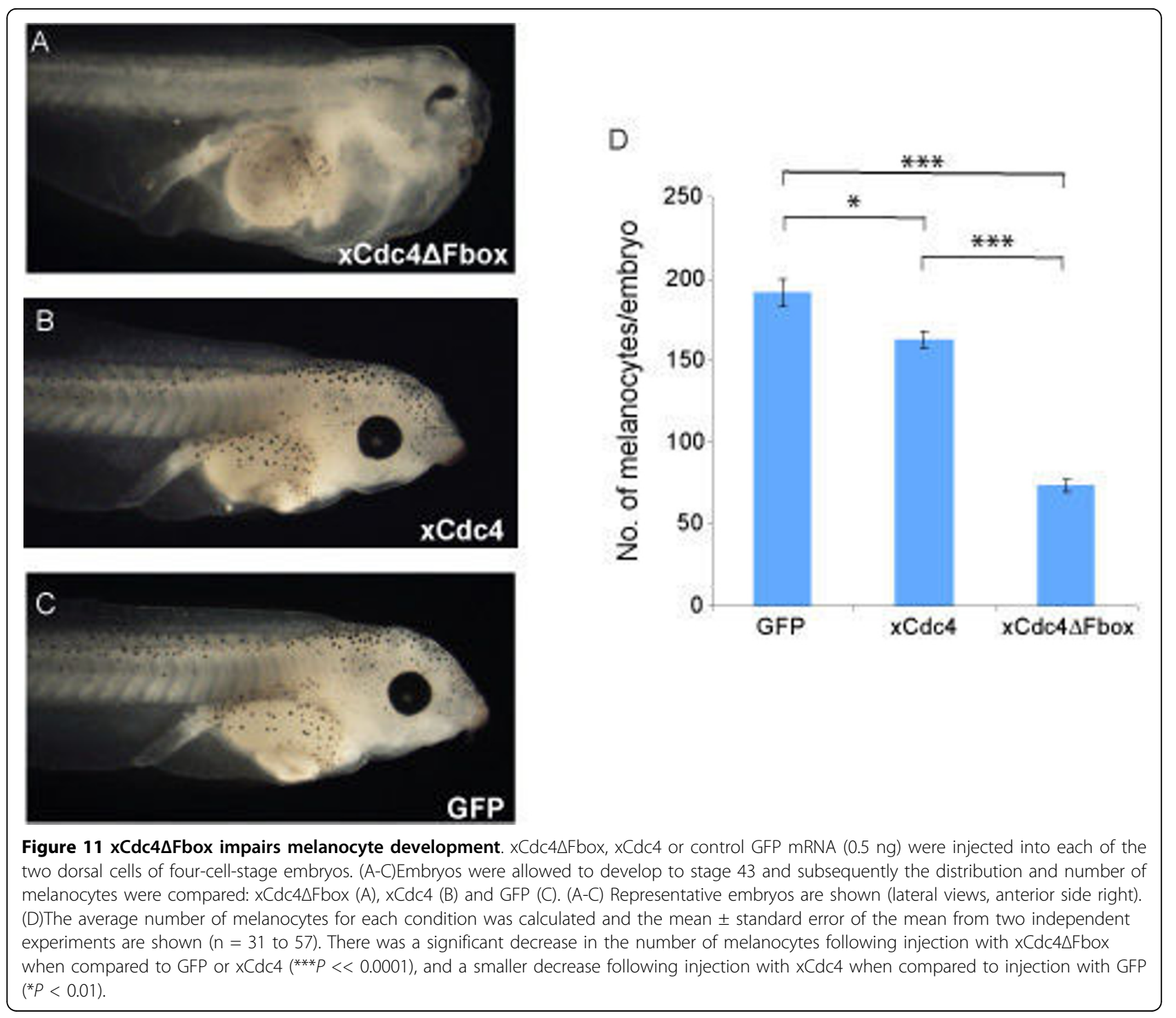

$\mathrm{xCdc} 4$ activity in other tissues where it is expressed, for example, the eye field (Figure 1I). As injected mRNA is not thought to persist much beyond tailbud stages, these defects most likely result from a requirement for $\mathrm{xCdc} 4$ at these earlier stages.

Since $\mathrm{xCdc} 4 \Delta \mathrm{Fbox}$ did not result in an increase in cycling cells that could disrupt neural crest differentiation, we investigated the possibility that $\mathrm{xCdc} 4 \Delta \mathrm{Fbox}$ results in apoptosis of cells destined to become neural crest. TUNEL (terminal deoxynucleotidyltransferasemediated dUTP-biotin nick end labeling) staining was used to detect apoptotic cells following mRNA injection. No difference in TUNEL staining was observed following overexpression of $\mathrm{xCdc} 4 \Delta \mathrm{Fbox}$ (Figure 12A-D). Approximately $70 \%$ of embryos had TUNEL positive cells $(\mathrm{n}=100$ to 110$)$, but in no case were differences in
TUNEL staining observed, either in the neural folds or in the embryo as a whole.

We were surprised at the low frequency of TUNELpositive cells detected in this assay, although embryos that had been wounded were used as a positive control and were highly TUNEL-positive (data not shown). Therefore, an alternative assay for apoptosis was also used. We took advantage of the fact that hBclXL can block apoptosis in X. laevis $[19,40]$. We checked whether Snail2 expression in $\mathrm{xCdc} 4 \Delta$ Fbox injected embryos could be rescued by co-expression of hBclXL. $\mathrm{xCdc} 4 \Delta$ Fbox, $\mathrm{xCdc} 4$ or GFP (1 ng) were injected unilaterally into two-cell-stage embryos. In addition, $1 \mathrm{ng}$ of hBclXL or GFP were co-injected as appropriate. Whole mount ISH for Snail2 was performed on stage 18 embryos, and Snail2 staining in $\mathrm{xCdc} 4 \Delta \mathrm{Fbox} / \mathrm{hBclXL}$ - 


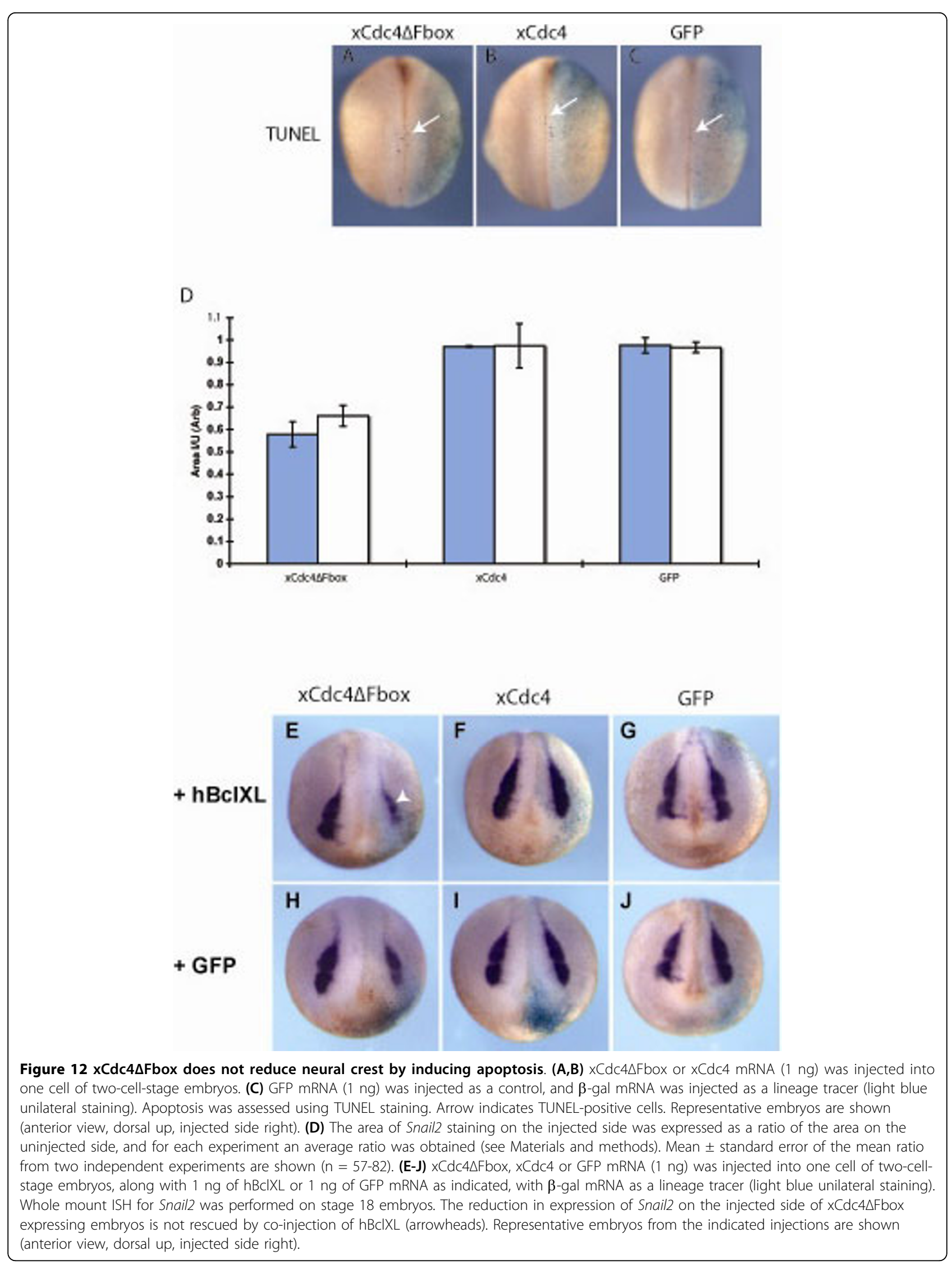


injected embryos was compared to $\mathrm{xCdc} 4 \Delta \mathrm{Fbox} / \mathrm{GFP}$ injected embryos ( $\mathrm{n}=57$ to 82; Figure 12E-J). In these experiments, $\mathrm{xCdc} 4 \Delta \mathrm{Fbox} / \mathrm{GFP}$-injected embryos displayed an average $32 \%$ reduction in Snail2 staining, compared to GFP-injected embryos (mean \pm SEM ratios were $0.66 \pm 0.05$ and $0.97 \pm 0.02$, respectively). However, no rescue of Snail2 staining was seen when hBclXL was co-injected with $\mathrm{xCdc} 4 \Delta \mathrm{Fbox}$, with an average $41 \%$ reduction in Snail 2 staining on the injected side compared to embryos injected with GFP/hBclXL. Thus, loss of neural crest after inhibition of $\mathrm{xCdc} 4$ activity is not due to tissue loss by apoptosis.

In summary, we have identified two homologues of Cdc4 in X. laevis that show dynamic expression in the early embryo, in particular in the developing neural crest and its derivatives. While unexpectedly having no effect on cell cycling, blocking $\mathrm{xCdc} 4$ function by overexpression of a dominant negative form of the protein resulted in inhibition of specification and formation of the neural crest. This had long-term consequences for the formation of neural crest derivatives such as melanocytes and cartilage. Thus, regulated and specific proteolysis by $\mathrm{xCdc} 4$ plays an essential function in early development distinct from its well-established role in regulating cell division.

\section{Discussion}

This work has identified a novel role for the F-box protein $\mathrm{xCdc} 4$ in neural crest development in $X$. laevis. Cdc4 orthologs in vertebrates have attracted considerable interest due to the plethora of substrates they degrade, and the fact that $\mathrm{Cdc} 4$ is a haplo-insufficient tumor suppressor protein $[10,16]$. However, the embryonic lethality of Cdc4 knock-out mice precluded a detailed analysis of the role of this protein in development [17].

$X$. laevis Cdc4 is likely to be orthologous to vertebrate $\mathrm{Cdc} 4$ for several reasons. Firstly, $\mathrm{xCdc} 4$ is highly conserved compared to human Cdc4, both in terms of sequence and apparent gene organization. Secondly, $\mathrm{xCdc} 4 \alpha$ and $\mathrm{xCdc} 4 \beta$ are capable of degrading Cyclin E, a known substrate of mammalian Cdc4. This validates the use of $X$. laevis to study the developmental function of Cdc4. In contrast, recovered $C d c 4^{-/-}$mouse embryos show profound vascular defects [17], precluding study in other developmental processes. Developing amphibian embryos do not require a functional vasculature until later embryonic stages, making this an excellent system for studying other functions of Cdc4.

In this work, we report the isolation of two $\mathrm{xCdc} 4$ isoforms, $\mathrm{xCdc} 4 \alpha$ and $\mathrm{xCdc} 4 \beta$. The genes encoding them are almost identical from the region corresponding to the second exon (1,622 out of 1,625 nucleotides identical). This strongly suggested that the structure of the
Xenopus gene was conserved compared to mammals. In humans and mice, the Cdc4 locus encodes three isoforms of Cdc4; designated $\alpha, \beta$ and $\gamma$. These are produced by alternative splicing of three unique 5 ' exons to ten common 3' exons, yielding proteins that differ only at their amino termini. Although our data suggest that this gene structure is preserved, no $\mathrm{xCdc} 4 \gamma$ isoform was detected during this work. In addition, in silico analysis, using the Ensembl genome browser, failed to detect sequences corresponding to the $\gamma$ specific exon.

To check if $\mathrm{xCdc} 4$ was functionally orthologous to vertebrate $\mathrm{Cdc} 4$, the ability of $\mathrm{xCdc} 4$ to degrade Cyclin $\mathrm{E}$ was examined. $\mathrm{xCdc} 4$ overexpression reduced the abundance of Cyclin E, compared to embryos coinjected with GFP, preferentially reducing the abundance of the slower migrating hyper-phosphorylated form of Cyclin E (Figure 6A). This is in agreement with previous findings that $\mathrm{Cdc} 4$ only interacts with phosphorylated Cyclin E [35-38]. xCdc4 also degrades Cyclin $\mathrm{E}$ in vivo, while $\mathrm{xCdc} 4 \Delta$ Fbox does not (Figure 6).

The spatio-temporal expression of $\mathrm{xCdc} 4$ was examined by immunoblotting for $\mathrm{xCdc} 4$ isoforms, and by whole mount ISH (Figure 1). Using antibodies that detected $\mathrm{xCdc} 4$, both isoforms were expressed at all stages tested. $\mathrm{xCdc} 4 \alpha$ migrated at an apparent molecular weight of $100 \mathrm{kDa}$, despite having a predicted molecular weight of $79 \mathrm{kDa}$ (Figure 1A). This is in keeping with a previous report that showed that human $\mathrm{Cdc} 4 \alpha$ migrated with an apparent molecular weight of $110 \mathrm{kDa}$, although its predicted molecular weight was $80 \mathrm{kDa}$ [9]. In contrast, $\mathrm{xCdc} 4 \beta$ consistently migrated slightly faster than its predicted molecular weight of $62 \mathrm{kDa}$ (Figure 1B).

Although expressed across the embryo, the neural crest and placodes were the first sites where $\mathrm{xCdc} 4$ transcripts accumulated most prominently (Figures 1, 2 and 4). Subsequently, transcripts were detected in the branchial arches and fin mesenchyme, which are both neural crest derived tissues, as well as in the somites and brain, and co-localized in many areas with other known markers of neural crest and placodes (Figures 1 and 2). In order to examine the function of $\mathrm{xCdc} 4$ during development, gain and loss of function experiments were performed. Translation-blocking morpholinos did not inhibit expression of endogenous $\mathrm{xCdc} 4 \alpha$ and $\mathrm{xCdc} 4 \beta$ (data not shown). One possible explanation for this was the maternal expression of the proteins. Therefore, an F-box deletion mutant was used as an alternative way to inhibit the function of $\mathrm{xCdc} 4$. $\mathrm{xCdc} 4 \Delta$ Fbox acted as a dominant negative inhibitor of $\mathrm{xCdc}^{2}$ 's ability to degrade Cyclin E (Figure 6) because it retains its ability to bind to substrate but cannot recruit the substrate to the rest of the SCF complex. The specificity of Fbox proteins resides in their substrate binding site, and 
F-box deletion mutants, which bind specifically to their substrate but not to the Skp1 component of the SCF E3 ligase complex, have been widely employed as reagents to block degradation of specific F-box targets. Confirming this, $\mathrm{xSkp} 2 \Delta$ Fbox did not inhibit $\mathrm{xCdc} 4$-mediated degradation of the protein. As $\mathrm{xCdc} 4$ is expressed strongly in the neural crest, we investigated the effect of overexpression of $\mathrm{xCdc} 4 \Delta \mathrm{Fbox}$ on development of this tissue.

Inhibition of $\mathrm{xCdc} 4$, using $\mathrm{xCdc} 4 \Delta \mathrm{Fbox}$, inhibited neural crest development, as determined by Snail2 and Snail ISHs (Figures 8, 9 and 10). This inhibition of neural crest development occurred at an early stage, upstream of $c-M y c$, reducing expression of a number of proteins acting as regulators of Snail2, Snail and $c-M y c$ (Figure 8). This indicates that $\mathrm{xCdc} 4$ is required for establishment of neural crest identity, rather than simply maintenance of that identity. Although expressed more broadly in ectodermal and mesodermal derivatives, we did not detect a requirement for $\mathrm{xCdc} 4$ function in specification or differentiation of other tissues, nor in patterning of the neural tube (Additional files 2, 3 and 5), strongly indicating a tissue-autonomous role in the neural crest.

The most well characterized role of $\mathrm{Cdc} 4$ is in regulating the cell cycle, and we investigated whether $\mathrm{xCdc} 4$ regulates cell cycling in the early $X$. laevis embryo. $\mathrm{xCdc} 4 \Delta$ Fbox overexpression did not perturb the cell cycle as determined by phH3 staining in these early embryos (Figure 7). The results from phH3 staining are consistent with previous observations that cell proliferation has a minor role in neural crest development; neural and neural crest induction has been reported to proceed normally when cell division was blocked from mid-gastrula stages onwards $[19,45]$.

$\mathrm{xCdc} 4 \Delta$ Fbox does not inhibit neural crest development through activation of an apoptotic program. The evidence for this is threefold: $\mathrm{xCdc} 4 \Delta \mathrm{Fbox}$ overexpression did not lead to a loss of $\beta$-gal staining expressed from co-injected mRNA; there was no change in TUNEL staining (Figure 12A-D); and finally, co-injection of hBclXL did not affect the ability of $\mathrm{xCdc} 4 \Delta \mathrm{Fbox}$ to block neural crest development (Figure 12E-J). X. laevis embryos can undergo apoptotic cell death from stage 10.5 onwards [46-48]. TUNEL analysis during embryonic development showed that only 50 to $60 \%$ of embryos had TUNEL-positive cells in the ectoderm prior to stage 18 [49]. After this stage a higher percentage of embryos were TUNEL-positive, but individual embryos displayed less TUNEL staining. In terms of neural crest development, Sox10 and Id3 depletion have been reported to increase TUNEL staining in the neural crest, but this was coupled to a reduction in cell proliferation [50,51]. However, it has been reported that inhibition of the cell cycle reduces clearance of apoptotic cells, meaning that cell cycle inhibition in these embryos may have led to increased TUNEL staining [52].

Previous studies have reported increased levels of apoptosis occurring in neural folds rather than other areas of the embryonic ectoderm $[47,49,53]$, and a number of genes involved in neural crest development possess anti-apoptotic activity (for example, $[53,54]$ ). It is possible that apoptosis regulates neural crest development in a stage-specific manner. For example, it may be important in defining the neural crest boundary, rather than for neural crest induction. However, as $\mathrm{xCdc} 4$ acts at an early stage of neural crest development, regulation of apoptosis may not be involved.

The identification of $\mathrm{Cdc} 4$ as a regulator of neural crest development adds to existing evidence that the ubiquitin proteasome system plays a role in the development of this tissue. Overexpression of dominant negative Cullin1, which is predicted to inhibit all SCF E3 ligases, expanded the neural crest in $X$. laevis. This was primarily due to stabilization of the Wnt pathway component $\beta$-catenin, although other substrates are likely to have been involved [55]. Recently, the F-box protein Ppa was shown to regulate neural crest development by degradation of Snail2 in X. laevis. Overexpression of Ppa inhibited neural crest development [26]. The related protein Snail is degraded by the F-box protein $\beta$-TRCP in tissue culture cells [56]. Thus, a number of proteins involved in neural crest development display dynamic expression patterns, and regulation by ubiquitinmediated proteolysis is emerging as a method to achieve this through activity of different E3 ligases that target distinct substrates.

What substrates is Cdc4 targeting to influence neural crest formation? c-Myc regulates neural crest development $[19,57]$ and can be degraded by Cdc4 [11,29], but we saw that $\mathrm{xCdc} 4 \Delta$ Fbox decreased c-Myc mRNA (Figure 8), indicating that $\mathrm{xCdc} 4$ also acts upstream of $\mathrm{c}$ Myc expression. Indeed, $\mathrm{xCdc} 4$ acts upstream of early regulators of neural crest, such as Pax3 and Msx1 (Figure 8 ). We hypothesized that $\mathrm{xCdc} 4$ was degrading a negative regulator of neural crest development. c-Jun is another known target of Cdc4 [12] and is expressed at the right time and place to be regulating neural crest formation, although its exact role is poorly understood $[58,59]$. We saw that overexpression of c-Jun did indeed inhibit Snail2 expression (Additional file 6). However, when we tested whether $\mathrm{xCdc} 4$ could target c-Jun protein for degradation in embryos by co-injection of mRNAs encoding these proteins, and performing immunoblotting against HA-tagged c-Jun, we saw no effect of $\mathrm{xCdc} 4$ on c-Jun levels (data not shown). From these results, it is not clear whether c-Jun is a target for Cdc4 in this developmental context, and in any case, an 
essential role for c-Jun in regulating neural crest formation in X. laevis has not been clearly demonstrated.

Identification of E3 ligase targets is challenging, and co-factors required for protein degradation may be active only in certain contexts. For example, it has been noted that Cdc4-mediated degradation of c-Jun in tissue culture cells required co-expression of Glycogen synthase kinase $3 \beta$ (GSK3 $\beta$ ) [60]. It will be important to now identify the in vivo targets of $\mathrm{Cdc} 4$ that regulate formation of the neural crest if we are to have a fuller understanding of the role of selective protein degradation in the development of this tissue.

\section{Conclusions}

Here we identify $\mathrm{xCdc} 4$ as a novel regulator of neural crest development in $X$. laevis, acting early in neural crest formation, potentially by regulation of c-Jun. These results demonstrate that Cdc4's role as a tumor suppressor protein may extend beyond its ability to regulate the cell cycle to an ability to directly regulate tissue differentiation.

\section{Materials and methods}

\section{Plasmids and constructs}

Expression of constructs was verified by immunoblotting embryo lysates after microinjection of capped mRNA.

$X$. laevis $C d c 4 \beta$ ( $x C d c 4 \beta$ ) was cloned by PCR from stage $20 \mathrm{cDNA}$. Primers used to obtain the full length coding sequence were: forward, 5'-ATGGGCTTCTACGGCAC-3'; reverse, 5'-CCTTCACTTCATGTCCACGTC-3'. $x C d c 4 \beta$ was cloned into pCS2+repaired to synthesize capped mRNA for microinjection. An F-box deletion mutant of $x C d c 4 \beta$ ( $x C d c 4 \beta \Delta F b o x$ ) was produced by PCR and triple ligation strategy. The F-box region of $x C d c 4 \beta$ (nucleotides 379 to 516 inclusive) was replaced with an AseI site (ATTAAT, amino acids Ile and Asn).

Primers 5'-GCAACCGAATTCACCACCATGGGCTT CTACGGCAC-3' and 5'-GGTTGCATTAATAAAGT CCCGCTGAAACTGG-3' were used to amplify $x C d c 4 \beta$ upstream of the F-box, and 5'-GCAACCATTAATGAAGATGGGATCGATGAGC-3' and 5'-GGTTGCCTCGA GTCACTTCATGTCCACGTC-3' were used to amplify $x C d c 4 \beta$ downstream of the F-box.

$X$. laevis $C d c 4 \alpha(x C d c 4 \alpha)$ was similarly cloned using cDNA derived from stage 7 embryos. Primers used to obtain the full length coding sequence were: forward, $5^{\text {'- }}$ GCTGGCTTTTGGAAATGAATCAGG-3'; reverse, 5'CTTCACTTCATGTCCACATCAAAGTCC-3'. $x C d c 4 \alpha$ was cloned into pGEM-T Easy (Promega, Madison, WI, USA) downstream of the SP6 promoter. The GenBank accession number is DQ666345. A single point mutation was introduced into this sequence (nucleotide G1946A in the coding sequence, resulting in G649D in the protein), to introduce an Asp residue that is conserved amongst vertebrates, to correct what was likely a cloning error; $\mathrm{xCdc} 4 \alpha(\mathrm{G})$ was much less potent at inhibiting formation of neural crest compared to $\mathrm{xCdc} 4 \alpha$ (D) (data not shown). XCdc4 $\alpha$ (D) also degraded Cyclin E more efficiently than $\mathrm{xCdc} 4 \alpha$ (G) (data not shown). Site directed mutagenesis was performed using a QuikChange ${ }^{\circ}$ Multi Site Directed Mutagenesis kit (Stratagene, La Jolla, California) according to the manufacturer's instructions. $x C d c 4 \alpha \Delta F b o x$ was produced by an identical method to that described for $x C d c 4 \beta \Delta F b o x$. X. laevis Skp2AFbox has been described elsewhere [39].

$X$. laevis c-Jun in pCS2+ (GenBank accession number AJ243954) was a kind gift of Professor Walter Knochel (Institute of Biochemistry, University of Ulm, Germany). Antibodies

Anti-Cdc4 monoclonal antibodies (3B7 and 3A9) were a kind gift from Dr Axel Behrens (CRUK). Anti-FLAG M2 conjugated to horse radish peroxidase (A8592; used at 1:1,000), anti-tubulin B512 (T5168; used at 1:2,000) and anti-rabbit IgG conjugated to alkaline phosphatase (A9919; used at 1:1,000) were from Sigma (St Louis, MO, USA). Horse radish peroxidase conjugated antirabbit and mouse IgG (NA943 and NA931; used at 1:5,000) were from Amersham (GE Healthcare, Uppsala, Sweden), rabbit anti-phH3 (06570; used at 1:1,000) was from Upstate (Millipore, Billerica, MA, USA) and alkaline phosphatase conjugated anti-digoxigenin fab fragments (11093274910; used at 1:5,000) were from Roche (Basel, Switzerland).

\section{Xenopus laevis embryo manipulation}

$X$. laevis embryos were obtained by hormone-induced egg laying and in vitro fertilization by standard methods. Unilateral injections into the animal pole of two-cell-stage embryos (unless otherwise indicated) were carried out with in vitro transcribed capped mRNA (Ambion, Austin, TX, USA). mRNA was injected at doses of up to $2 \mathrm{ng}$ in a volume of $10 \mathrm{nl}$, and $0.5 \mathrm{ng}$ of $\beta$-gal mRNA was coinjected as a lineage tracer. GFP mRNA was injected as a control. Embryos were staged according to [61] and grown to the required stage. They were fixed in MEMFA ( $4 \%$ formaldehyde, $100 \mathrm{mM}$ MOPS, $2 \mathrm{mM}$ EGTA, $1 \mathrm{mM} \mathrm{MgSO}_{4}$, $\mathrm{pH}$ 7.4), washed in phosphate-buffered saline (PBS)/2 mM $\mathrm{MgCl}_{2}$, and stained with $1 \mathrm{mg} / \mathrm{ml} \mathrm{X}$-gal (5-bromo-4chloro-3-indolyl-beta-D-galactopyranoside) in X-gal mixer $\left(5.35 \mathrm{mM} \mathrm{K}_{3} \mathrm{Fe}(\mathrm{CN})_{6}, 5.35 \mathrm{mM} \mathrm{K}_{4} \mathrm{Fe}(\mathrm{CN})_{6}, 1.2 \mathrm{mM}\right.$ $\mathrm{MgCl}_{2}, 0.1 \%$ sodium deoxycholate, $0.2 \% \mathrm{NP}-40$ in PBS). Alternatively, embryos were stained with $1.7 \mathrm{mg} / \mathrm{ml}$ Red$\mathrm{gal}^{\circ}$ (6-chloro-3-indolyl-beta-D-galactopyranoside) in Xgal mixer. Embryos were washed in PBS, dehydrated in methanol and stored at $-20^{\circ} \mathrm{C}$.

\section{In situ hybridization}

Whole mount ISH was performed using a BioLane ${ }^{\mathrm{Tm}}$ HTI in situ robot (Holle and Huttner (Tubingen, Germany). 
The washes and composition of solutions were as described in [62], with some modifications in the protocol. The RNase step was omitted, and embryos were blocked with 2\% Blocking Reagent (Roche) and 20\% heat inactivated lamb serum in maleic acid buffer. Incubation with 1:5,000 anti-digoxigenin was performed in the same solution. The color reaction was terminated using PBS washes and embryos were re-fixed in MEMFA. Embryos were bleached as described in [62]. $x C d c 4$ in pBSK+ was linearized with Pst I and transcribed T3 for antisense, and linearized with NotI and transcribed T7 for sense. The following probes were used: $c-M y c, M s x I$ [53], Opl/Zic1 [32], Pax3 [30], Snail, Six1 [34], Sox2, Sox10 [31] and Snail2 [25].

To quantify the area of Snail2 expression, Openlab ${ }^{\text {tw }}$ software (Improvision/Perkin Elmer, Waltham, MA, USA) was used to select the area of Snail2 staining on the injected (I) and uninjected (U) side, using all injected embryos unless they were damaged. For each experiment the average ratio of $\mathrm{I} / \mathrm{U}$ was determined for each injection to determine the change in Snail2 staining on the injected side, a ratio of $<1$ indicating Snail2 reduction. For at least two experiments, a mean ratio \pm standard error of the mean (SEM) for each injection was calculated by taking the mean of the average ratios, and a Student's $t$-test performed. The ratios were compared to GFP-injected control embryos.

ISH on sectioned embryos was performed as described in [63]. Stage 15 to 22 embryos were fixed in MEMFA, embedded in a paraffin and beeswax solution and sectioned using a Leica microtome. The ISH was performed on 14- $\mu \mathrm{m}$ sections using $x C d c 4$ and Snail2 probes. The slides were mounted using Aquamount (BDH-Merck, VWR International, West Chester, PA, USA).

\section{Whole mount antibody staining}

Whole mount antibody staining, using anti-phH3, was performed as described in [62]. The chromogenic reaction was developed as described, using $0.45 \mathrm{mg} / \mathrm{ml}$ Nitroblue tetrazolium chloride (NBT; Roche) and 0.2 $\mathrm{mg} / \mathrm{ml}$ 5-bromo-4-chloro-3-indolyl-phosphate (BCIP; Roche) in alkaline phosphatase buffer.

TUNEL staining to detect apoptotic cells

Embryos were devitellinized, fixed in MEMFA, stained for $\beta$-gal and bleached. They were washed in $1 \times$ Terminal Deoxynucleotidyl Transferase (TdT) buffer (Invitrogen, Paisley, UK); $100 \mathrm{mM}$ potassium cacodylate $\mathrm{pH} 7.2$, $2 \mathrm{mM} \mathrm{CoCl}_{2}$ and $0.2 \mathrm{mM}$ dithiothreitol) and incubated overnight at room temperature in $\mathrm{TdT}$ buffer with 0.5 $\mu \mathrm{M}$ alkaline stable digoxigenin-11-dUTP (Roche) and $150 \mathrm{U} / \mathrm{ml}$ recombinant TdT (Invitrogen). The TdT reaction was stopped by washing embryos at $65^{\circ} \mathrm{C}$ with PBST (phosphate-buffered saline, 0,1\% Tween 20)/1 mM EDTA. Overnight incubation of the embryos in
PBST $/ 20 \%$ heat inactivated goat serum with anti-digoxigenin was performed at $4^{\circ} \mathrm{C}$. Embryos were washed with PBS, and staining was developed using NBT/BCIP.

\section{Analysis of melanocyte distribution}

Embryos were injected with $0.5 \mathrm{ng}$ of $\mathrm{xCdc} 4 \Delta \mathrm{Fbox}$, $\mathrm{xCdc} 4$ or control GFP mRNA into each of the two animal dorsal cells of four-cell-stage embryos. At stage 43, the embryos were fixed in MEMFA and dehydrated overnight in ethanol. For the examination of melanocytes, individual embryos were photographed, the anterior region selected and the number of melanocytes counted using Image J software. For each condition, the number of melanocytes was averaged, the mean \pm SEM was calculated and a Student's $t$-test performed.

\section{Western blotting}

Embryos were lysed in $100 \mathrm{mM} \mathrm{NaCl}, 5 \mathrm{mM}$ EDTA, $0.1 \%$ Triton $\mathrm{X}-100$ and $50 \mathrm{mM} \beta$-glycerophosphate. Cleared supernatants were mixed with an equal volume of $2 \times$ SDS gel loading buffer (100 mM Tris pH 6.8, 4\% SDS, $20 \%$ glycerol and $0.2 \%$ bromophenol blue), and dithiothreitol was added to a final concentration of 100 $\mathrm{mM}$. One embryo equivalent per lane was loaded. In order to quantify protein levels, blots were imaged by using infrared fluorescence of appropriately tagged secondary antibodies and quantified by using a LiCOR Biosciences (Lincoln, Nebraska, USA) Odyssey scanner and software.

\footnotetext{
Additional file 1: Alignment of $X$. laevis Cdc4 isoforms to hCdc4 $\alpha$ and hCdc $4 \beta$. ClustalW alignment of human (HU) and X. laevis (XI) $\mathrm{Cdc} 4 \alpha$ and $\mathrm{Cdc} 4 \beta$. XI Cdc4 $\alpha$ shows $88 \%$ identity to HU Cdc $4 \alpha$. Similarly, XI Cdc $4 \beta$ shows $86 \%$ identity to HU Cdc $4 \beta$. Black boxes denote nuclear localization signals for $\mathrm{XI}$ and $\mathrm{HU} \mathrm{Cdc} 4 \alpha$; red box indicates F-Box motif; green boxes outline WD40 repeat region. Domain assignments were made using the Pfam program at the Sanger Centre [64]. The putative dimerization domain of Cdc4 (based on [646566] is shown as a black dashed line. Grey regions indicate identity while blue signifies similar amino acids. A single point mutation was introduced into $x \mathrm{Cdc} 4 \alpha$ (nucleotide G1946A in the coding sequence, resulting in G649D in the protein) to introduce an Asp residue (denoted by red text at position 649) that is conserved amongst vertebrates, to correct what was most likely a cloning error.

Click here for file

[http://www.biomedcentral.com/content/supplementary/1749-8104-5-1S1.JPEG ]

Additional file 2: $\mathrm{xCdc} 4 \Delta \mathrm{Fbox}$ does not affect anterior-posterior axis patterning. We injected $1 \mathrm{ng}$ of $\mathrm{xCdc} 4 \Delta \mathrm{Fbox}(\mathrm{A}, \mathrm{B}, \mathrm{E}, \mathrm{F}, \mathrm{I}, \mathrm{J})$ or $\mathrm{xCdc} 4 \mathrm{mRNA}$ $(C, G, K)$ into one cell of two-cell-stage embryos; 1 ng of GFP mRNA $(D, H$, L) was injected as a control and $\beta$-gal mRNA was co-injected as a lineage tracer. Stage 16 to 18 embryos were stained for the forebrain/ anterior midbrain marker Otx2 (A-D), the midbrain/hindbrain junction marker En2 (E-H), or the hindbrain marker Krox20 (I-L). Representative embryos from three independent pooled experiments are shown $(n=38$ to 79; anterior view, dorsal up, injected side right). Numbers represent the percentages of embryos displaying each phenotype and white arrows highlight differences in expression of the markers on the injected side.

Click here for file

[http://www.biomedcentral.com/content/supplementary/1749-8104-5-1S2.JPEG]
} 
Additional file 3: $x C d c 4 \Delta F b o x$ does not affect development of the myotome, the epidermis or primary neurons. $x C d c 4 \triangle F b o x, x C d c 4$ or control GFP mRNA (1 ng) was injected into one cell of two-cell-stage embryos. $\beta$-gal was co-injected as a lineage tracer. ISH was performed on stage 13 to 15 embryos for MyoD (A-C) and epidermal keratin (EK) (GI), on stage 15 embryos for neural $\beta$-tubulin (N $\beta T)(\mathrm{J}-\mathrm{L})$ and at stage 18 to 20 for heavy chain myosin (HCM) (D-F). Representative embryos for the indicated injection are shown (dorsal view, anterior up, injected side on the right). Numbers are the percentage of embryos with normal phenotypes ( $n=59$ to 109).

Click here for file

[http://www.biomedcentral.com/content/supplementary/1749-8104-5-1S3.JPEG ]

\section{Additional file 4: The F-box protein xSkp2 does not affect neural} crest development. xSkp2 or xSkp2 $\triangle$ Fbox mRNA (2 ng) was injected into one cell of two-cell-stage embryos. GFP mRNA (2 ng) was injected as a control. $\beta$-gal mRNA was co-injected as a lineage tracer. ISH for Snail2 was performed on stage 18 embryos. As an additional control, ISH was performed in parallel for $N \beta T$ on stage 15 embryos. (A-C)

Representative embryos (anterior view, dorsal up, injected side on the right) from Snail2 ISH for each injection. Numbers are the percentage of embryos displaying each phenotype (pooled data from two experiments; $n=53$ to 61). (D-F) Representative embryos (dorsal view, anterior up, injected side on the right) injected with the indicated mRNA, from $N \beta T$ ISH. Numbers are the percentage of embryos displaying each phenotype ( $n=49$ to 52 ). White arrows indicate reduced primary neurons on the injected side of the embryo.

Click here for file

[http://www.biomedcentral.com/content/supplementary/1749-8104-5-1S4.JPEG ]

Additional file 5: $x C d c 4 \Delta$ Fbox does not affect placode development $x C d c 4 \triangle F b o x, x C d c 4$ or control GFP mRNA (1 ng) was injected into one cell of two-cell-stage embryos. $\beta$-gal was co-injected as a lineage tracer ISH was performed on stage 16 to 18 embryos for the placodal marker Six1 ( $n=49$ to 86). (A-C) Representative embryos are shown for the indicated injections (dorsal view, anterior up, injected side right). Numbers represent the percentage of normal embryos.

Click here for file

[http://www.biomedcentral.com/content/supplementary/1749-8104-5-1S5.JPEG ]

\section{Additional file 6: c-Jun is a negative regulator of neural crest}

development. c-Jun mRNA (0.5 ng or $1 \mathrm{ng}$ ) was injected into one cell of two-cell-stage embryos. GFP mRNA was injected as a control, and $\beta$-gal mRNA was injected as a lineage tracer (light blue unilateral staining). Whole mount ISH was performed for Snail2 (A-C) or C-Myc (D-F) expression. The area of Snail2 staining on the injected side was expressed as a ratio of the area on the uninjected side. The mean \pm SEM ratio ( $n=37$ to 87 ) is shown for each injection. Representative embryos are shown (anterior view, dorsal up, injected side right). The average percentage reduction in Snail2 staining on the injected side, compared to embryos injected with GFP, is shown for Snail2 ISHs. For c-Myc ISHs, the percentage of embryos showing the phenotype is displayed. Click here for file

[http://www.biomedcentral.com/content/supplementary/1749-8104-5-1S6.JPEG ]

\section{Abbreviations}

GFP: green fluorescent protein; ISH: in situ hybridization; PBS: phosphatebuffered saline; phH3: phosphorylated histone H3; Ppa: Partner of paired; RING: Really Interesting New Gene; SCF: Skp1-Cullin1-F-box; SEM: standard error of the mean; TdT: Terminal Deoxynucleotidyl Transferase; TUNEL: terminal deoxynucleotidyltransferase-mediated dUTP-biotin nick end labeling.

\section{Acknowledgements}

The authors gratefully acknowledge Dr Axel Behrens (CRUK) for supplying the anti-Cdc4 antibodies, and Therese Mitchell, Alison Jones and Dr lan
Horan for technical assistance. HMW was funded by a Wellcome Trust studentship. ADA was funded by a Fundacao Ciencia e Tecnologia studentship and CJH by a CRUK studentship. Work in AP's lab is funded by MRC Research Grants G0500101 and G0700758. Work in RSH's lab is funded by a grant from the National Cancer Institute-National Institutes of Health (R01CA095898).

\section{Author details}

${ }^{1}$ Department of Oncology, University of Cambridge, Hutchison-MRC Research Centre, Addenbrookes Hospital, Hills Road, Cambridge, CB2 OXZ, UK. ${ }^{2}$ Current address: Division of Virology, Department of Pathology, University of Cambridge, Tennis Court Road, CB2 1QP, UK. ${ }^{3}$ Program in Molecular Biology and Biotechnology, University of North Carolina at Chapel Hill, Chapel Hill, NC 27599, USA. ${ }^{4}$ Department of Cell Biology and Physiology, and Cancer Center, University of New Mexico Health Sciences Center, Albuquerque, NM 87131, USA.

\section{Authors' contributions}

ADA and HMW are joint first co-authors.

AP conceived the study, participated in its experimental design and coordination, and helped draft and refine the manuscript. HMW participated in study design, designed and undertook experiments and produced the first draft of the manuscript. HMW, MKS and RSH contributed to generation of new reagents and coordinated the collaboration. ADA designed and undertook the experiments during the revision of the manuscript. AP, HMW, ADA, CJH, MKS and RSH helped refine the manuscript. HMW was the sole contributor to Figures 5, 6, 7, and 12 and Additional files 2, 3, 4, 5 and 6, and the primary contributor to Figure 8. ADA was the primary contributor to Figures 2, 3, 4, 9, 10 and 11. HMW and ADA contributed to Figure 1. MKS was the primary contributor of Additional file 1. ADA and $\mathrm{CJH}$ contributed to Figure 8. HMW, ADA, CJH, RSH and AP analyzed and interpreted the data. All authors read and approved the final manuscript.

\section{Competing interests}

The authors declare that they have no competing interests.

Received: 27 January 2009

Accepted: 4 January 2010 Published: 4 January 2010

\section{References}

1. Semple CA: The comparative proteomics of ubiquitination in mouse. Genome Res 2003, 13:1389-1394.

2. Zheng N, Schulman BA, Song L, Miller JJ, Jeffrey PD, Wang P, Chu C, Koepp DM, Elledge SJ, Pagano M, et al: Structure of the Cul1-Rbx1-Skp1-F boxSkp2 SCF ubiquitin ligase complex. Nature 2002, 416:703-709.

3. Skowyra D, Craig KL, Tyers M, Elledge SJ, Harper JW: F-box proteins are receptors that recruit phosphorylated substrates to the SCF ubiquitinligase complex. Cell 1997, 91:209-219.

4. Bai C, Sen P, Hofmann K, Ma L, Goebl M, Harper JW, Elledge SJ: SKP1 connects cell cycle regulators to the ubiquitin proteolysis machinery through a novel motif, the F-box. Cell 1996, 86:263-274.

5. Hartwell LH, Mortimer RK, Culotti J, Culotti M: Genetic Control of the Cell Division Cycle in Yeast: V. Genetic Analysis of cdc Mutants. Genetics 1973, 74:267-286.

6. Verma R, Feldman RM, Deshaies RJ: SIC1 is ubiquitinated in vitro by a pathway that requires CDC4, CDC34, and cyclin/CDK activities. Mol Biol Cell 1997, 8:1427-1437.

7. Verma R, Annan RS, Huddleston MJ, Carr SA, Reynard G, Deshaies RJ: Phosphorylation of Sic1p by $\mathrm{G} 1 \mathrm{Cdk}$ required for its degradation and entry into S phase. Science 1997, 278:455-460.

8. Feldman RM, Correll CC, Kaplan KB, Deshaies RJ: A complex of Cdc4p, Skp1p, and Cdc53p/cullin catalyzes ubiquitination of the phosphorylated CDK inhibitor Sic1p. Cell 1997, 91:221-230.

9. Strohmaier H, Spruck CH, Kaiser P, Won KA, Sangfelt O, Reed SI: Human Fbox protein hCdc4 targets cyclin E for proteolysis and is mutated in a breast cancer cell line. Nature 2001, 413:316-322.

10. Welcker M, Clurman BE: FBW7 ubiquitin ligase: a tumour suppressor at the crossroads of cell division, growth and differentiation. Nat Rev Cancer 2008, 8:83-93.

11. Yada M, Hatakeyama S, Kamura T, Nishiyama M, Tsunematsu R, Imaki H, Ishida N, Okumura F, Nakayama K, Nakayama KI: Phosphorylation- 
dependent degradation of c-Myc is mediated by the F-box protein Fbw7. Embo J 2004, 23:2116-2125.

12. Nateri AS, Riera-Sans L, Da Costa C, Behrens A: The ubiquitin ligase SCFFbw7 antagonizes apoptotic JNK signaling. Science 2004, 303:13741378.

13. Moberg KH, Bell DW, Wahrer DC, Haber DA, Hariharan IK: Archipelago regulates Cyclin E levels in Drosophila and is mutated in human cancer cell lines. Nature 2001, 413:311-316.

14. Oberg C, Li J, Pauley A, Wolf E, Gurney M, Lendahl U: The Notch intracellular domain is ubiquitinated and negatively regulated by the mammalian Sel-10 homolog. J Biol Chem 2001, 276:35847-35853.

15. Kitagawa K, Hiramatsu Y, Uchida C, Isobe T, Hattori T, Oda T, Shibata K, Nakamura S, Kikuchi A, Kitagawa M: Fbw7 promotes ubiquitin-dependent degradation of c-Myb: involvement of GSK3-mediated phosphorylation of Thr-572 in mouse c-Myb. Oncogene 2009, 28:2393-2405.

16. Mao JH, Perez-Losada J, Wu D, Delrosario R, Tsunematsu R, Nakayama Kl, Brown K, Bryson S, Balmain A: Fbxw7/Cdc4 is a p53-dependent, haploinsufficient tumour suppressor gene. Nature 2004, 432:775-779.

17. Tsunematsu R, Nakayama K, Oike Y, Nishiyama M, Ishida N, Hatakeyama S, Bessho Y, Kageyama R, Suda T, Nakayama Kl: Mouse Fbw7/Sel-10/Cdc4 is required for notch degradation during vascular development. J Biol Chem 2004, 279:9417-9423.

18. Cornell RA, Eisen JS: Notch in the pathway: the roles of Notch signaling in neural crest development. Semin Cell Dev Biol 2005, 16:663-672.

19. Bellmeyer A, Krase J, Lindgren J, LaBonne C: The protooncogene c-myc is an essential regulator of neural crest formation in xenopus. Dev Cell 2003, 4:827-839.

20. Meulemans D, Bronner-Fraser M: Gene-regulatory interactions in neural crest evolution and development. Dev Cell 2004, 7:291-299.

21. Steventon B, Carmona-Fontaine C, Mayor R: Genetic network during neural crest induction: from cell specification to cell survival. Semin Cell Dev Biol 2005, 16:647-654.

22. Le Douarin NM, Creuzet S, Couly G, Dupin E: Neural crest cell plasticity and its limits. Development 2004, 131:4637-4650.

23. Huang $X$, Saint-Jeannet JP: Induction of the neural crest and the opportunities of life on the edge. Dev Biol 2004, 275:1-11.

24. Aybar MJ, Nieto MA, Mayor R: Snail precedes slug in the genetic cascade required for the specification and migration of the Xenopus neural crest. Development 2003, 130:483-494.

25. Mayor R, Morgan R, Sargent MG: Induction of the prospective neural crest of Xenopus. Development 1995, 121:767-777.

26. Vernon $A E$, LaBonne $C$ : Slug stability is dynamically regulated during neural crest development by the F-box protein Ppa. Development 2006, 133:3359-3370.

27. Spevak W, Keiper BD, Stratowa C, Castanon MJ: Saccharomyces cerevisiae cdc15 mutants arrested at a late stage in anaphase are rescued by Xenopus CDNAs encoding $\mathrm{N}$-ras or a protein with beta-transducin repeats. Mol Cell Biol 1993, 13:4953-4966.

28. Lin HR, Chuang LC, Boix-Perales H, Philpott A, Yew PR: Ubiquitination of cyclin-dependent kinase inhibitor, Xic1, is mediated by the Xenopus Fbox protein xSkp2. Cell Cycle 2006, 5:304-314.

29. Welcker M, Orian A, Jin J, Grim JE, Harper JW, Eisenman RN, Clurman BE: The Fbw7 tumor suppressor regulates glycogen synthase kinase 3 phosphorylation-dependent c-Myc protein degradation. Proc Natl Acad SCi USA 2004, 101:9085-9090.

30. Hong CS, Saint-Jeannet JP: The activity of Pax3 and Zic1 regulates three distinct cell fates at the neural plate border. Mol Biol Cell 2007, 18:21922202.

31. Aoki Y, Saint-Germain N, Gyda M, Magner-Fink E, Lee YH, Credidio C, SaintJeannet JP: Sox 10 regulates the development of neural crest-derived melanocytes in Xenopus. Dev Biol 2003, 259:19-33.

32. Nakata K, Nagai T, Aruga J, Mikoshiba K: Xenopus Zic family and its role in neural and neural crest development. Mech Dev 1998, 75:43-51.

33. Schlosser $G$, Ahrens $K$ : Molecular anatomy of placode development in Xenopus laevis. Dev Biol 2004, 271:439-466.

34. Pandur PD, Moody SA: Xenopus Six 1 gene is expressed in neurogenic cranial placodes and maintained in the differentiating lateral lines. Mech Dev 2000, 96:253-257.

35. Koepp DM, Schaefer LK, Ye X, Keyomarsi K, Chu C, Harper JW, Elledge SJ: Phosphorylation-dependent ubiquitination of cyclin E by the SCFFbw7 ubiquitin ligase. Science 2001, 294:173-177.
36. Welcker M, Singer J, Loeb KR, Grim J, Bloecher A, Gurien-West M, Clurman BE, Roberts JM: Multisite phosphorylation by Cdk2 and GSK3 controls cyclin E degradation. Mol Cell 2003, 12:381-392.

37. Ye X, Nalepa G, Welcker M, Kessler BM, Spooner E, Qin J, Elledge SJ, Clurman BE, Harper JW: Recognition of phosphodegron motifs in human cyclin E by the SCF(Fbw7) ubiquitin ligase. J Biol Chem 2004, 279:5011050119.

38. Hao B, Oehlmann S, Sowa ME, Harper JW, Pavletich NP: Structure of a Fbw7-Skp1-cyclin E complex: multisite-phosphorylated substrate recognition by SCF ubiquitin ligases. Mol Cell 2007, 26:131-143.

39. Boix-Perales H, Horan I, Wise H, Lin HR, Chuang LC, Yew PR, Philpott A: The E3 ubiquitin ligase Skp2 regulates neural differentiation independent from the cell cycle. Neural Develop 2007, 2:27.

40. Richard-Parpaillon L, Cosgrove RA, Devine C, Vernon AE, Philpott A: G1/S phase cyclin-dependent kinase overexpression perturbs early development and delays tissue-specific differentiation in Xenopus. Development 2004, 131:2577-2586.

41. Rempel RE, Sleight SB, Maller JL: Maternal Xenopus Cdk2-cyclin E complexes function during meiotic and early embryonic cell cycles that lack a G1 phase. J Biol Chem 1995, 270:6843-6855.

42. Sangfelt O, Cepeda D, Malyukova A, van Drogen F, Reed SI: Both SCF (Cdc4alpha) and SCF(Cdc4gamma) are required for cyclin E turnover in cell lines that do not overexpress cyclin E. Cell Cycle 2008, 7:1075-1082.

43. Vernon AE, Philpott $A$ : The developmental expression of cell cycle regulators in Xenopus laevis. Gene Expr Patterns 2003, 3:179-192.

44. Saka Y, Smith JC: Spatial and temporal patterns of cell division during early Xenopus embryogenesis. Dev Biol 2001, 229:307-318.

45. Harris WA, Hartenstein V: Neuronal determination without cell division in Xenopus embryos. Neuron 1991, 6:499-515.

46. Anderson JA, Lewellyn AL, Maller JL: lonizing radiation induces apoptosis and elevates cyclin A1-Cdk2 activity before but not after the midblastula transition in Xenopus. Mol Biol Cell 1997, 8:1195-1206.

47. Hensey C, Gautier J: A developmental timer that regulates apoptosis at the onset of gastrulation. Mech Dev 1997, 69:183-195.

48. Stack JH, Newport JW: Developmentally regulated activation of apoptosis early in Xenopus gastrulation results in cyclin A degradation during interphase of the cell cycle. Development 1997, 124:3185-3195.

49. Hensey C, Gautier J: Programmed cell death during Xenopus development: a spatio-temporal analysis. Dev Biol 1998, 203:36-48.

50. Honore SM, Aybar MJ, Mayor R: Sox10 is required for the early development of the prospective neural crest in Xenopus embryos. Dev Biol 2003, 260:79-96.

51. Kee Y, Bronner-Fraser M: To proliferate or to die: role of Id3 in cell cycle progression and survival of neural crest progenitors. Genes Dev 2005, 19:744-755.

52. Yeo W, Gautier J: A role for programmed cell death during early neurogenesis in xenopus. Dev Biol 2003, 260:31-45.

53. Tribulo C, Aybar MJ, Sanchez SS, Mayor R: A balance between the antiapoptotic activity of Slug and the apoptotic activity of $\mathrm{ms} \times 1$ is required for the proper development of the neural crest. Dev Biol 2004, 275:325342.

54. Vega S, Morales AV, Ocana OH, Valdes F, Fabregat I, Nieto MA: Snail blocks the cell cycle and confers resistance to cell death. Genes Dev 2004, 18:1131-1143.

55. Voigt J, Papalopulu N: A dominant-negative form of the E3 ubiquitin ligase Cullin-1 disrupts the correct allocation of cell fate in the neural crest lineage. Development 2006, 133:559-568.

56. Yook Jl, Li XY, Ota I, Fearon ER, Weiss SJ: Wnt-dependent regulation of the E-cadherin repressor snail. J Biol Chem 2005, 280:11740-11748.

57. Barembaum M, Bronner-Fraser M: Early steps in neural crest specification. Semin Cell Dev Biol 2005, 16:642-646.

58. Knochel S, Schuler-Metz A, Knochel W: c-Jun (AP-1) activates BMP-4 transcription in Xenopus embryos. Mech Dev 2000, 98:29-36.

59. Peng Y, Xu RH, Mei JM, Li XP, Yan D, Kung HF, Phang JM: Neural inhibition by c-Jun as a synergizing factor in bone morphogenetic protein 4 signaling. Neuroscience 2002, 109:657-664.

60. Wei W, Jin J, Schlisio S, Harper JW, Kaelin WG Jr: The v-Jun point mutation allows c-Jun to escape GSK3-dependent recognition and destruction by the Fbw7 ubiquitin ligase. Cancer Cell 2005, 8:25-33.

61. Nieuwkoop PD, Faber J: Normal table of Xenopus laevis. New York: Garland Publishing 1994. 
62. Sive HL, Grainger RL, Harland RM: Early Development of Xenopus laevis. A Laboratory Manual Cold Spring Harbour Laboratory Press 2000.

63. Butler K, Zorn AM, Gurdon JB: Nonradioactive in situ hybridization to xenopus tissue sections. Methods 2001, 23:303-312.

64. Zhang W, Koepp DM: Fbw7 isoform interaction contributes to cyclin E proteolysis. Mol Cancer Res 2006, 4:935-943.

65. Welcker $\mathrm{M}$, Clurman $\mathrm{BE}: \mathrm{Fbw} 7 / \mathrm{hCDC} 4$ dimerization regulates its substrate interactions. Cell Div 2007, 2:7.

66. Tang $X$, Orlicky S, Lin Z, Willems A, Neculai D, Ceccarelli D, Mercurio F, Shilton BH, Sicheri F, Tyers M: Suprafacial orientation of the SCFCdc4 dimer accommodates multiple geometries for substrate ubiquitination. Cell 2007, 129:1165-1176.

doi:10.1186/1749-8104-5-1

Cite this article as: Almeida et al:: The F-box protein Cdc4/Fbxw7 is a novel regulator of neural crest development in Xenopus laevis. Neural Development 2010 5:1.

Publish with Biomed Central and every scientist can read your work free of charge

"BioMed Central will be the most significant development for disseminating the results of biomedical research in our lifetime. " Sir Paul Nurse, Cancer Research UK

Your research papers will be:

- available free of charge to the entire biomedical community

- peer reviewed and published immediately upon acceptance

- cited in PubMed and archived on PubMed Central

- yours - you keep the copyright 